\title{
Ontogeny of the Sexually Dimorphic Sonic Muscle in Three Sciaenid Species
}

Gary Hill

College of William and Mary - Virginia Institute of Marine Science

Follow this and additional works at: https://scholarworks.wm.edu/etd

Part of the Aquaculture and Fisheries Commons, and the Developmental Biology Commons

\section{Recommended Citation}

Hill, Gary, "Ontogeny of the Sexually Dimorphic Sonic Muscle in Three Sciaenid Species" (1985).

Dissertations, Theses, and Masters Projects. Paper 1539617558.

https://dx.doi.org/doi:10.25773/v5-tjgj-2305

This Thesis is brought to you for free and open access by the Theses, Dissertations, \& Master Projects at W\&M ScholarWorks. It has been accepted for inclusion in Dissertations, Theses, and Masters Projects by an authorized administrator of W\&M ScholarWorks. For more information, please contact scholarworks@wm.edu. 


\title{
ONTOGENY OF THE SEXUALLY DIMORPHIC SONIC MUSCLE
}

IN THREE SCIAENID SPECIES

\author{
A Thesis \\ Presented to \\ The Faculty of the Department of Ichthyology \\ Virginia Institute of Marine Science \\ The College of William and Mary in Virginia
}

In Partial Fulfillment

Of the Requirements for the Degree of

Master of Arts
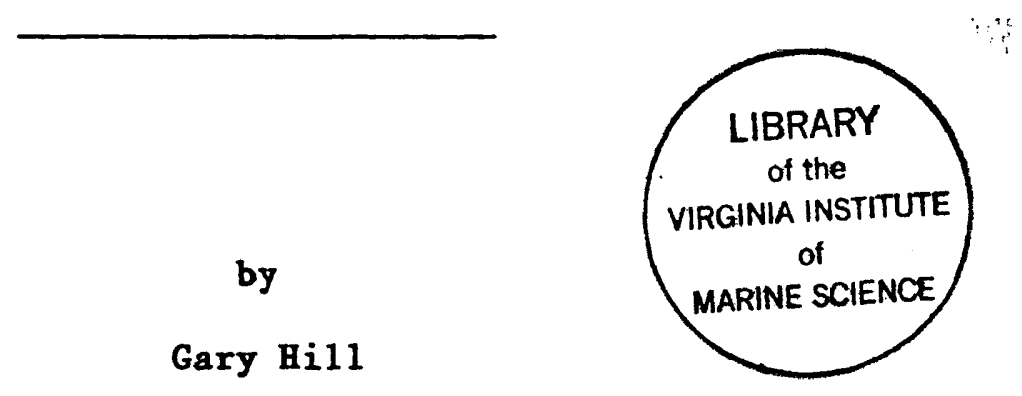

1985 
APPROVAL SHEET

This thesis is submitted in partial fulfillment of the requirements for the degree of

Master of Arts

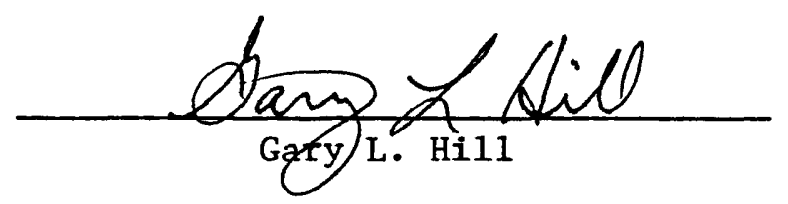

Approved, August 1985
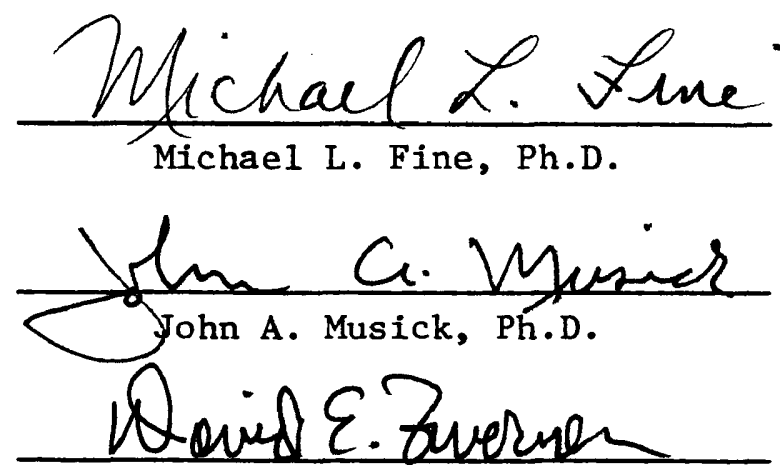

David E. Zwerner, M.A.

Enrique m. Bumpers

Eugene M. Burreson, Ph.D.

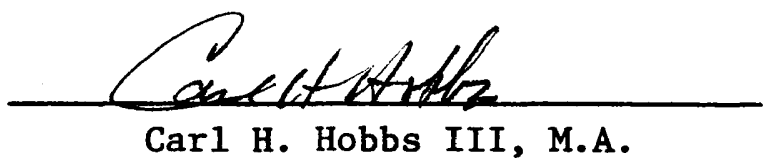


TABLE OF CONTENTS

\section{PAGE}

ACKNOWLEDGEMENTS $\ldots \ldots \ldots \ldots \ldots \ldots \ldots \ldots \ldots \ldots \ldots \ldots \ldots \ldots \ldots \ldots \ldots \ldots \ldots \ldots \ldots \ldots$

LIST OF TABLES...................................

LIST OF FIGURES ....................................vi

ABSTRACT $\ldots \ldots \ldots \ldots \ldots \ldots \ldots \ldots \ldots \ldots \ldots \ldots \ldots \ldots \ldots \ldots \ldots \ldots \ldots \ldots \ldots \ldots$

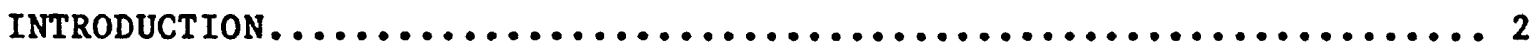

MATERIALS AND METHODS ................................ 6

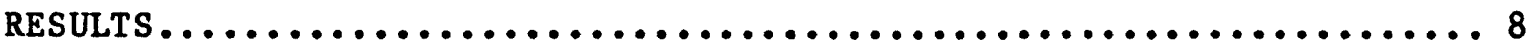

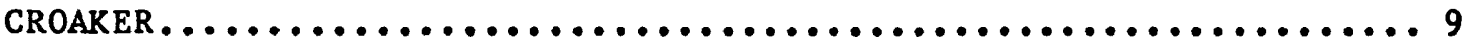

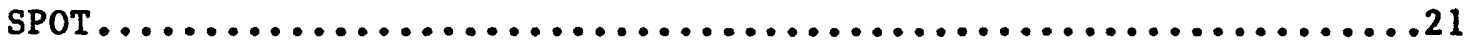

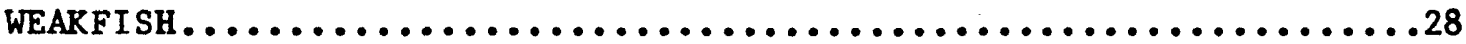

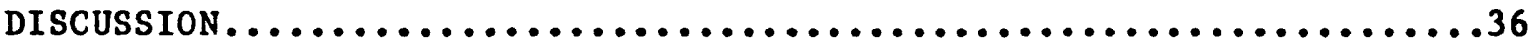

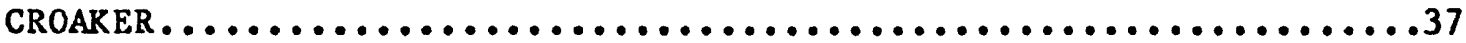

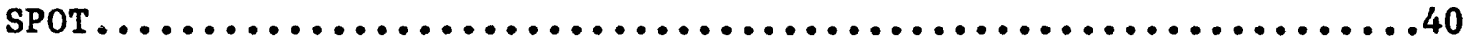

WEARFISH. ..........................................

SUMMARY AND CONCLUSION

CROAKER........................................47

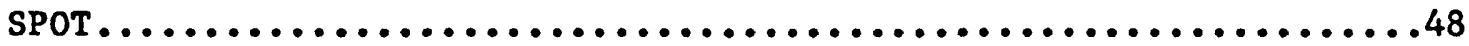

WEAKFISH...............................................

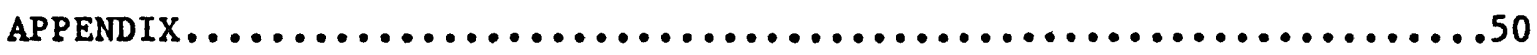

LITERATURE CITED....................................

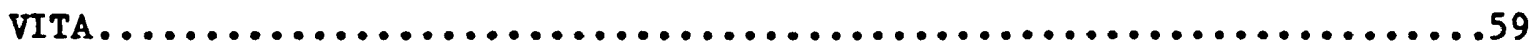




\section{ACRNOWLEDGEMENTS}

I wish to express my appreciation to Dr. Mike Fine and Dr. Jack Musick, co-chairmen of my thesis committee, for suggestion of this problem, for guidance during the course of this study, and for helpful criticism during the writing of the thesis. I also wish to thank my committee members Mr. Dave Zwerner, Dr. Gene Burreson, and Mr. Woody Hobbs for helpful suggestions throughout the study, and for critique of the manuscript. Additional thanks to Dave Zwerner for instruction in histology and help in preparation of gonadal material and to Gene Burreson for providing space in the wet lab during preliminary investigations .

I also express grateful appreciation to the following VIMS personnel: Dennis Thoney for his help in photographing gonadal tissue; Bob Harris for extensive help in computer programing; Bill Jenkins and Kay Stubblefield for help and consideration in the Photo and Art Departments; and Steve $0^{\prime}$ Neil for providing literature on sciaenids. Thanks to Steve Ross for collection of sciaenids off the coast of North Carolina. I would also like to thank Paul Gerdes and the manly men of the VIMS trawl survey for their assistance in collecting specimens. Special thanks 80 to my parents for their considerable moral support and understanding throughout the course of my graduate studies. This paper was supported by NIH Grant MH38921. 


\section{LIST OF TABLES}

TABLE

PAGE

1 Presentation of statistical data calculated for each

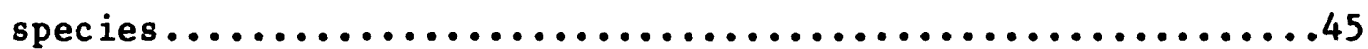

2 Correlation of data on sexual maturity, muscle development, and spawning season...................46 
1 Regression of sonic muscle weight against body weight for male and female croaker of body weights

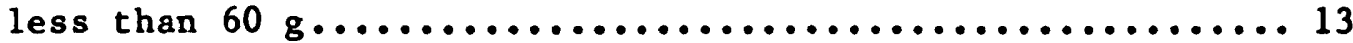

2 Regression of sonic muscle weight against body weight for male and female croaker........................ 14

3 Regression of body weight against standard length for male and female croaker............................ 15

4 Regression of sonic muscle weight and gonad weight against body weight for ma le croaker.................. 16

5 Regression of sonic muscle weight and gonad weight against body weight for female croaker................. 17

6 (1) Photomicrograph of immature test is in $109 \mathrm{~mm}$ S.L. male croaker. (2) Photomicrograph of developing testis in $182 \mathrm{~mm} \mathrm{S.L.} \mathrm{male} \mathrm{croaker} \mathrm{showing} \mathrm{active}$ spermatogenesis .................................. 18

7 (1) Photomicrograph of immature ovary in $93 \mathrm{~mm}$ S.L. female croaker. (2) Photomicrograph of developing ovary in $188 \mathrm{~mm} \mathrm{S.L.} \mathrm{female} \mathrm{croaker} \mathrm{showing} \mathrm{early}$ stage of gametogenesis.............................19

8 Regression of swimbladder weight against body weight for male and female croaker........................ 20

9 Regression of sonic muscle weight against body weight

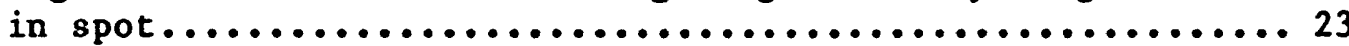

10 Regression of body weight against standard length in spot........................................ 24

11 Regression of sonic muscle weight and gonad weight against body weight in spot......................... 25

12 Photomicrograph of immature testis in $158 \mathrm{~mm}$ S.L. male spot...................................... 26

13 Regression of swimbladder weight against body weight for male and female spot............................ 
14 Regression of sonic muscle weight against body

weight in weakfish.............................. 30

15 Regression of body weight against standard length

in weakfish.................................. 31

16 Regression of sonic muscle weight and gonad weight

against body weight in weakfish.................... 32

17 (1) Photomicrograph of developing test is in $119 \mathrm{~mm}$ S.L. male weakfish. (2) Photomicrograph of developing testis in same specimen showing area undergoing early stage of spermatogenesis ........................... 33

18 Photomicrograph of developing test is in $148 \mathrm{~mm}$ S.L. male weakfish undergoing active spermatogenesis.......... 34

19 Regression of swimbladder weight against body weight for male and female weakfish...................... 35 


\begin{abstract}
The ontogeny of the swimbladder and sexually dimorphic sonic muscles were examined in three sciaenid species - croaker (Micropogonias undulatus), spot (Leiostomus xanthurus) and weakfish (Cynoscion regalis). In croaker, both sexes possessed the sonic muscles, but they grew larger and heavier in males than in females. Muscle development began at the same standard length in both sexes (45 mm S.L.) when the fish were approximately 4 to 5 months old and the gonads were starting to develope, but before the onset of gametogenesis. Spot sonic muscle occured only in males and first appeared at $105 \mathrm{~mm}$ S.L. at approximately 6 to 7 months of age, before maturation of the gonads. Weakfish sonic muscle was present in males only, and first appeared at $119 \mathrm{~mm}$ S.L. at approximately 11 months of age, concurrent with gonadal maturation. Sonic muscle development was synchronous with the growth of the gonads in all three species. Swimbladders grew larger in male croakers than in females, but there was no sexual difference in swimbladder size in spot or weakfish.
\end{abstract}


ONTOGENY OF THE SEXUALLY DIMORPHIC SONIC MUSCLE

IN THREE SCIAENID SPECIES 
Introduction

The family Sciaenidae is among the largest of sound producing fishes with some 150 species within 30 genera (Ono and Poss, 1981). Sound production in sciaenids occurs through contraction of extrinsic muscles lateral to the swimbladder which originate on the central tendon overlying the dorsal surface of the swimbladder and insert, via connective tissue, to the lateral wall of the body cavity (Tower, 1908). Contractions of the sonic muscles cause the swimbladder walls to vibrate, producing the characteristic sound (Tower, 1908). Differences in swimbladder shape may be responsible for the different frequencies of sound produced in various sciaenid species (Chao, 1978) although no experimental work has been done. Swimbladders range from a simple carrot shape (Leiostomus xanthurus) to a similar carrot shape with additional diverticula (Micropogonias undulatus) to the twochambered swimbladders of Stellifer and Bairdie1la (Chao, 1978). Most species are sexually dimorphic with sonic muscle occuring only in males: weakfish (Cynoscion regalis) and related species (ㅁ. nebulosis and $\underline{\text {. }}$ jamaicensis), silver perch (Bairdiella chrysoura), the ground drummer (ㅁ. ronchus), the star drum (Stellifer lanceolatus), and spot (Leiostomus xanthurus) (Fish and Mowbray, 1970). An exception is the croaker (Micropogonias undulatus) in which both males and females 
possess the muscle. Tower (1908), however, observed a much thicker and heavier drumming muscle in the male, suggesting differences in sound production. Sciaenid species of the genera Menticirrhus and Lonchurus have greatly reduced or degenerate swimbladders and can produce no sound in this manner.

The sexual dimorphism of sonic muscle is not restricted to sciaenid fishes. Male haddock (Melanogrammus aeglefinus) have larger sonic muscles than females especially during the spawning season (Templeman and Hodder, 1956). Sexual dimorphism also occurs in the bladder muscles of some species of ophidioids and macrourids. Males of some oviparous ophidioids have drumming muscles while the females muscles are vestigial or absent (Marshall, 1967). Males of Barathrodemus manatinus a deep-sea ophidioid, possess two pairs of muscles while the female has only one pair (Carter and Musick, 1985). Further, Fine (1975) demonstrated sexual dimorphism in the rates of growth of swimbladders in toadfish, with those of males growing faster than those of females. Sound production in toadfish has also been shown to vary sexual1y. Although both sexes possess the intrinsic swimbladder muscle, only males produce the courtship boatwhist le call (Gray and Winn, 1961). Males also are more prone to grunt throughout the year, though females do participate in this vocalization (Gray and Winn, 1961). Thus, the sonic muscle of these species, like those of the Sciaenidae, apparently play a role in reproductive behavior. Sound production in sciaenids occurs most prevalently during reproductive periods (Dijkgraaf, 1947; Fish, 1954; Fish and Cummings, 
1972; Takemura et a1., 1977; Guest and Lasswe11, 1978), a1though the sounds produced are not necessarily a direct part of reproduction. For instance, vocalizations are produced by males in response to the presence of conspecific males during pairing in Corvina nigra (Dijkgraaf, 1947), and are produced by male weakfish (Cynoscion regalis) when pursued or captured by experimenters (Fish, 1954). Thus, sounds may be generated in response to territorial aggression, avoidance, or stress. In other species, the production of sound appears to be part of courtship behavior. Male red drum (Sciaenops ocellata), for example, produce their most intense sounds just before spawning (Guest and Lasswel1, 1978).

The histology and ultrastructure of the sonic muscle was investigated in weakfish (Cynoscion regalis) by Ono and Poss (1981). Swimbladder muscle fibers average $29.6 \pm 5.3 \mathrm{um}$ in diameter with myofibrils radially arranged around a core of densely packed mitochondria, glycogen, and sarcoplasmic reticulum. Most myofibrils have a consistent width with some bifurcating as they extend from the center to the periphery. Mitochondria occur both in the central cisternae of the muscle fiber and surrounding the myofibrils. Innervation occurs through an apparently variable number of segmental nerves associated with spinal nerves 3 or 4 to 9,10 , or 11 (Ono and Poss, 1981). Although the gross morphology of the swimbladder and sonic muscles of a number of sciaenids has been examined (Marsha11, 1962; Chao, 1978; Ono and Poss, 1981;), no one has formally investigated the ontogeny of the sonic muscles. Many fish species go through a juvenile 
phase in which they possess gonads that are not morphologically distinguishable as to sex. Since sonic muscles in most sciaenids are a secondary sex character present only in the males, it is an interesting question as to what stage of development these muscles differentiate in.

The purpose of this study are to examine and quantify growth of both the sonic muscles and swimbladder, to determine the size at which the sonic muscle becomes visually evident in three sciaenid species croaker (Micropogonias undulatus), spot (Leiostomus xanthurus) and weakfish (Cynoscion regalis), and to correlate these data with state of gonadal differentiation. Additionally, the study attempts to determine whether the muscles of male croaker grow larger and heavier than those of females as suggested by Tower (1908). 
Materials and Methods

Three species of sciaenids (Micropogonias undulatus, Leiostomus xanthurus, Cynoscion regalis) were collected in trawls from the York River and Chesapeake Bay and from off the coast of North Carolina. Specimens were preserved in $10 \%$, neutral, buffered formalin and later measured for standard length (S.L.), weight, swimbladder weight, sonic muscle weight, and muscle length and width. Selected gonadal tissues were embedded in paraffin, sectioned at $7 \mathrm{um}$, and stained with hematoxylin and eosin in order to assess degree of maturation. Maturation of sectioned gonadal tissue was determined through reference to Overstreet (1983). Immature individuals were sexed macroscopically through differences in morphology of the gonad. Immature testes were cylindrical in shape and consistently thin along their length. Ovaries were thicker in diameter but truncated to a much shorter length.

Dissections of the swimbladder and observations on the presence or absence of the sonic muscle were performed macroscopically. Sonic muscle was first separated from the lateral wall using a blunt probe and scalpel and extracted a long with the swimbladder from the body cavity. Muscle tissue was then separated from the central tendon overlying the swimbladder. Muscle and aponeurosis could be differentiated by coloration and texture. Swimbladders and sonic muscles were weighed to $0.1 \mathrm{mg}$ with a Metler B5 balance and muscle length and width were measured to $0.1 \mathrm{~mm}$ with a ruler. Measurements of length and width were made on both sonic muscles, one of which lies on 
either side of the swimbladder. Length was defined as the anterior posterior axis. The length and width of both right and left sonic muscle and other data are presented in Appendices A through C. The data were used to determine when swimbladder muscles first appear and to document the development of the muscle with respect to time. Regressions of sonic muscle weight and swimbladder weight against body weight were calculated as were regressions of sonic muscle weight against gonad weight, and body weight against standard length. Evaluation of differences between male and female croaker muscles was performed by analysis of covariance using a computer program written by Joseph L. Russo following statistical procedures outlined by J.H. Zar (1974). An analysis of covariance was also utilized to evaluate swimbladder weight differences between males and females of all three species. Analyses of regressions of spot and weakfish data were performed using the Statistical Package for Social Sciences (SPSS) program. 


\section{Resu1ts}

In all three species the sonic muscle was first observed as a thin, clear mass attached to and projecting from the central tendon which overlies the dorsal surface of the swimbladder. As development of the muscle proceeded, the width of the muscle extended farther down the sides of the abdominal cavity until it met or approached the ventral surface of the body cavity. The muscle's length was established soon after the muscle initially appeared and extended along most (approximately 3/4) of the surface of the swimbladder. The ratio of muscle length to swimbladder length remained constant with continued growth of the fish. Croaker muscle extended along both sides of the abdominal wall from the swimbladder to the ventral surface where both halves of the muscle met and attached to the abdomina 1 wa 11 by connective tissue. The connective tissue was visible as a lateral white band on each half of the muscle upon dissection, having been severed as the ventral surface of the body cavity was opened. As the sonic muscle thickened with growth, color changed slightly from a transparent or cloudy white to a red or brown-red hue. Spot sonic muscle did not extend to the ventral midline of the body cavity as in croaker. Instead, the muscle reached down to only about $3 / 4$ of the abdominal wall, and was much thinner than croaker muscle. Spot sonic muscle was transparent or cloudy white in small individuals to a very light red in larger specimens. Weakfish muscle, similar to spot sonic 
muscle, extended ventrally to only about $3 / 4$ of the surface of the abdominal wall. The two halves originated, as did spot and croaker muscle, on the dorsal surface of the swimbladder from a common aponeurosis. The sonic muscle of weakfish was thick, similar to croaker, and deep red in hue.

I did note a difference in sound producing capabilities between croaker, spot and weakfish. When captured, croaker actively vocalized and the abdominal cavity vibrated noticeably. Sounds produced were loud and continued throughout measurement and weighing. Spot, however, could not be heard vocalizing unless held close to the ear and vibrations of the abdominal cavity could be felt, but only slightly. The weaker sounds produced in spot are probably due to the smaller size of the sonic muscle as compared to croaker. In fish of comparable weights, spot muscle is much lighter than that of croaker. Weakfish also produced intense sound, as might be expected from the thickness of their muscle.

\section{Croaker}

Ninety-eight croaker, collected from the last of April through July, 1984, ranged in standard length (S.L.) from 43 to $190 \mathrm{~mm}$. Sonic muscles were not observed in a male and female at standard lengths of $43 \mathrm{~mm}$ and $44 \mathrm{~mm}$ respectively. The smallest individuals with swimbladder muscles were a male and a female of $45 \mathrm{~mm}$ S.L. with sonic muscle weights of $0.4 \mathrm{mg}$ and $1.3 \mathrm{mg}$ respectively (Appendix A). The 
muscles at this stage of development were extremely thin and too small to measure macroscopically, but were discernable from the aponeurosis primarily through differences in texture and color. The largest sonic muscles taken from a female were found in a fish of $188 \mathrm{~mm} \mathrm{S.L.} \mathrm{and}$ weighed $1.74 \mathrm{~g}$. A larger female of $190 \mathrm{~mm} \mathrm{~S} . \mathrm{L}$. had a muscle weight considerably lighter at $1.61 \mathrm{~g}$. The largest sonic muscles taken from a male weighed $2.11 \mathrm{~g}$ from a specimen of $184 \mathrm{~mm} \mathrm{S.L.}$

In the earliest stages of development of the swimbladder muscle (body weights up to $60 \mathrm{~g}$ ) there was no significant difference in weight of muscle between males and females (Fig. 1; Table 1). (Comparative length measurements of all body weights given in text can be found in Fig. 3.) Regression lines were not significantly different ( $F=2.6762$; $d f=1,63 ; p=0.1068)$. Equation of best $f$ it line for females was: Muscle weight $=-0.0419+0.0099($ Body weight $) ;$ and for males was: Muscle weight $=-0.0531+0.0110$ (Body weight). As the body weight of the fish increased above $60 \mathrm{~g}$, however, the sonic muscle of males grew at a faster rate and became larger and heavier than that of females (Fig. 2). An analysis of covariance was performed on body weights ranging from 50 to $105 \mathrm{~g}$ (Table 1). Regressions for males and females differed significantly $(F=9.8345 ; d f=1,24 ; p=0.0044)$. Thus, the size of male sonic muscle exceeded that of the female over body weights of from $50 \mathrm{~g}$ to $105 \mathrm{~g}$. Regression 1 ines for all data points (up to $168 \mathrm{~g}$ ) were also significantly different $(F=53.3584 ; d f=1,92 ; p=0.0001)$. Equation of best fit line for females was: Muscle weight $=-0.03563+0.0096$ (Body weight); and for males was: Muscle weight $=-0.1074+0.0135$ (Body 
weight) (Table 1). Differences in growth of the muscle with respect to sex can also be seen in larger specimens by comparing measurements of length and width (Appendix A).

Initiation of sonic muscle growth was concurrent with gonadal development (Fig. 4 and 5) and there was a significant correlation between gonad growth and sonic muscle growth in males and females $\left(R^{2}=\right.$ 0.934 in females; $R^{2}=0.785$ in males). Muscle development began at 1.8 $\mathrm{g}$ in males and $1.9 \mathrm{~g}$ in females. At that same body weight, the gonads were just beginning to increase in weight. Thus, at weights below 1.8 or $1.9 \mathrm{~g}$, muscle weights were not observed and gonad weights were near zero. At very nearly the same point at which the rate of gonad growth increased, sonic muscle development was initiated. The gonads continued maturing at a rate which was in synchrony with that of the sonic muscle.

Select gonadal tissue was sectioned and examined histologically to determine the presence or absence of gametogenesis. A male at 109 mm S.L. (Fig. 6-1) and a female at $93 \mathrm{~mm} \mathrm{S.L.} \mathrm{(Fig.} \mathrm{7-1)} \mathrm{were} \mathrm{both}$ found to be immature - gametogenesis was not yet occuring. At the opposite extreme, a male of $182 \mathrm{~mm}$ S.L. was observed to be undergoing active spermatogenesis with all stages of spermatazoa present (Fig.62). A female of $188 \mathrm{~mm} \mathrm{S.L.} \mathrm{was} \mathrm{just} \mathrm{undergoing} \mathrm{development} \mathrm{of} \mathrm{oocytes}$ (Fig. 7-2). Although sonic muscle developes along with gonadal development, the muscles differentiate long before sexual maturity. Swimbladder weights were also tested by analysis of covariance (Fig. 8; Table 1.) to determine if differences existed between males 
and females. Regression lines were significantly different $(F=11.7285$; $d f=1,91 ; p=0.0009)$. Equation of best $f i t$ line for females was: Swimbladder weight $=-0.0149+0.0129$ (Body weight); and for males was: Swimbladder weight $=-0.0676+0.0152$ (Body weight). Male swimbladders grew to a heavier size than those of females. 
FIGURE 1. Regression of sonic muscle weight against body weight for male and female croaker of body weights less than $60 \mathrm{~g}$.

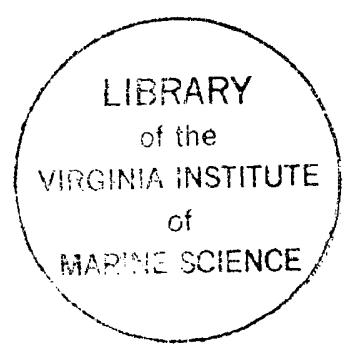




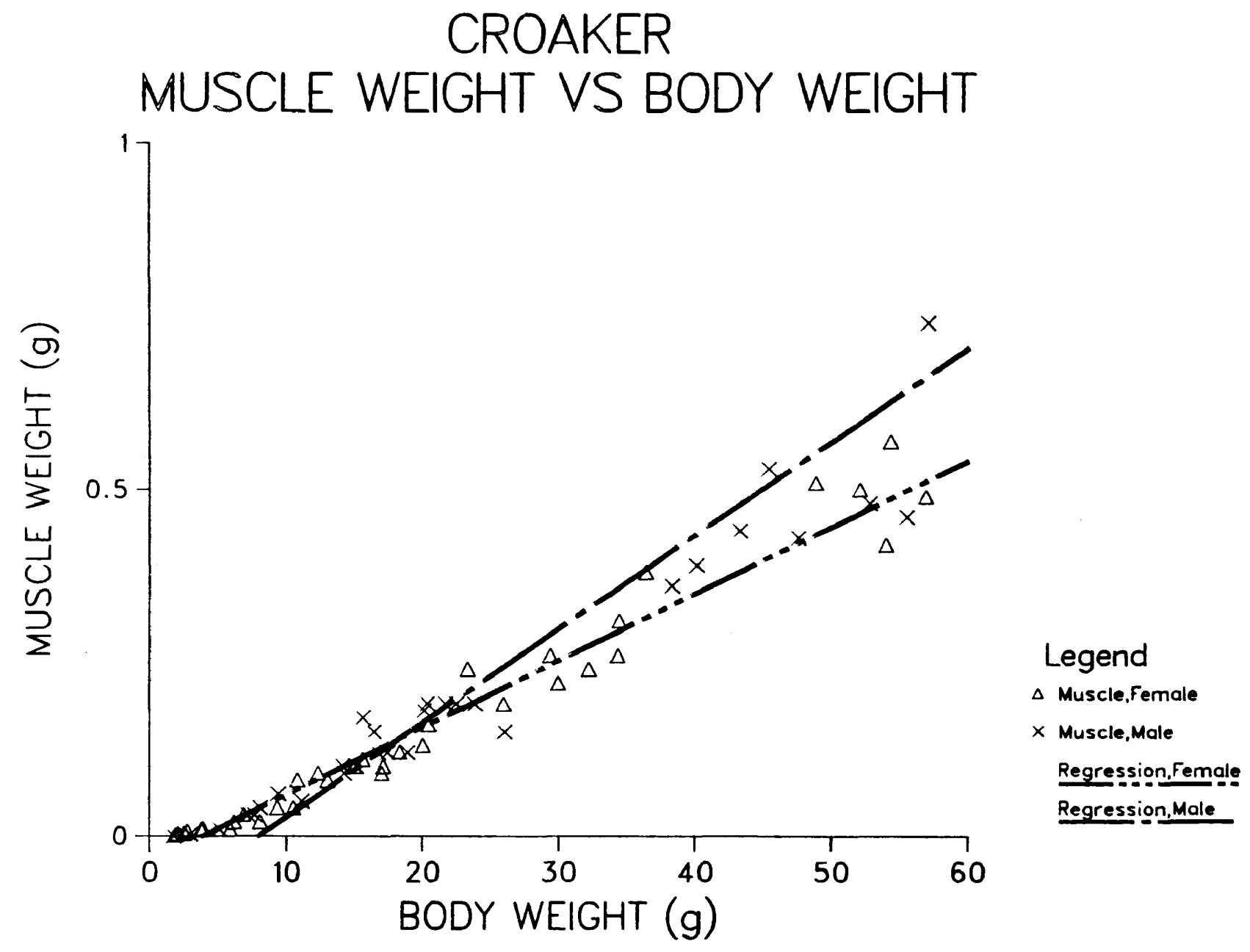


FIGURE 2. Regression of sonic muscle weight against body weight for male and female croaker (including all specimens). 


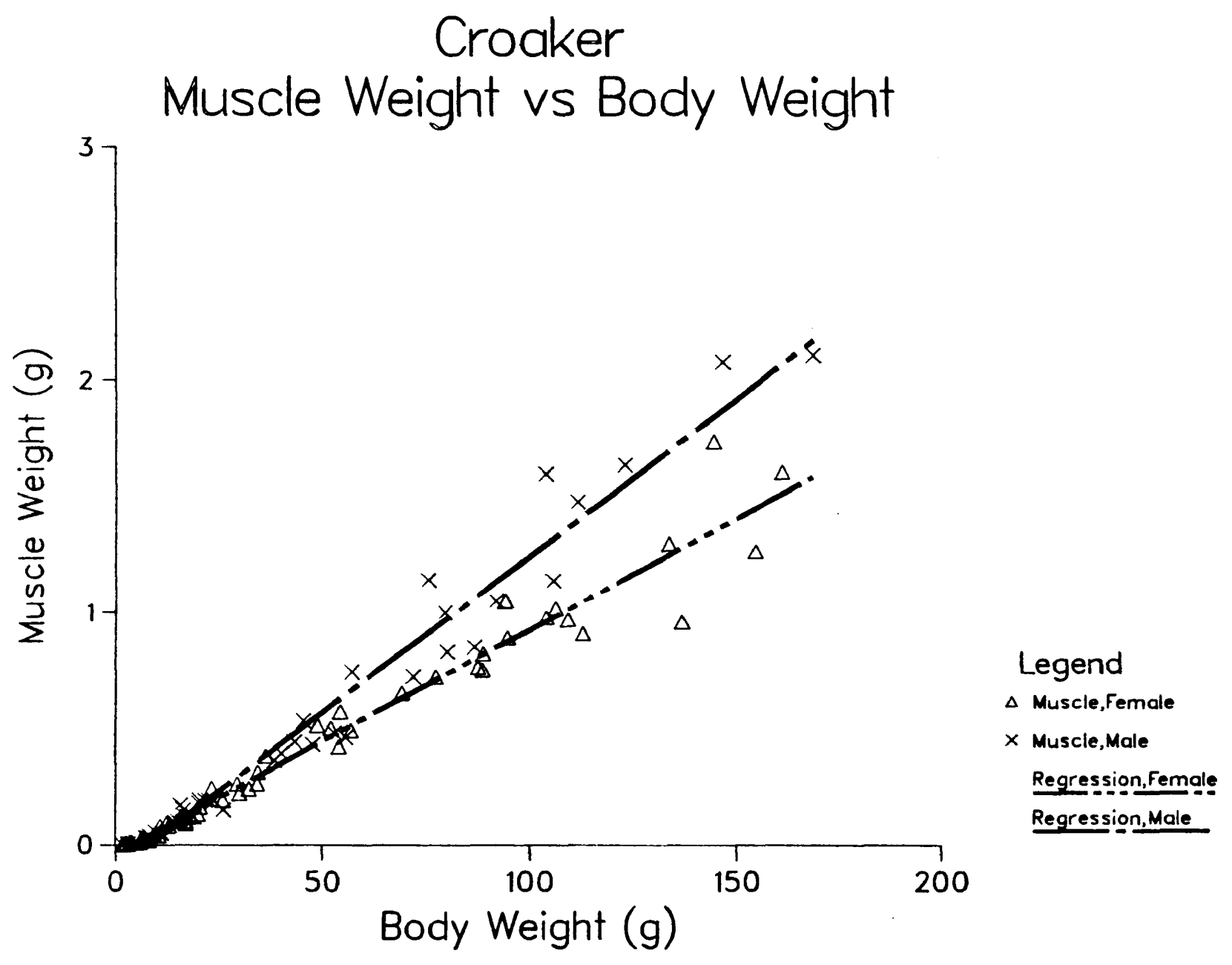


FIGURE 3. Regression of body weight against standard length for male and female croaker. 


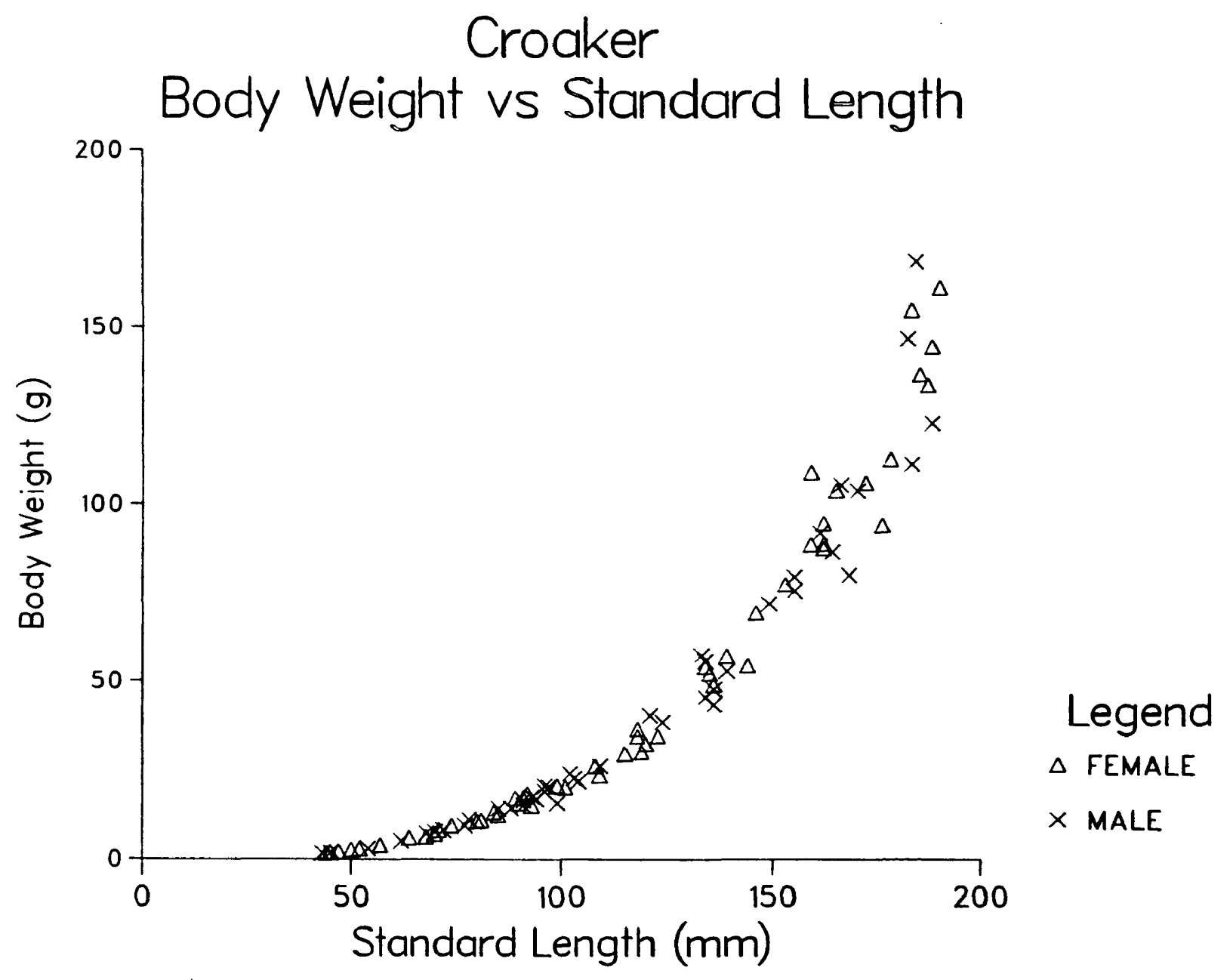


FIGURE 4. Regression of sonic muscle and gonad weight against body weight in male croaker. 


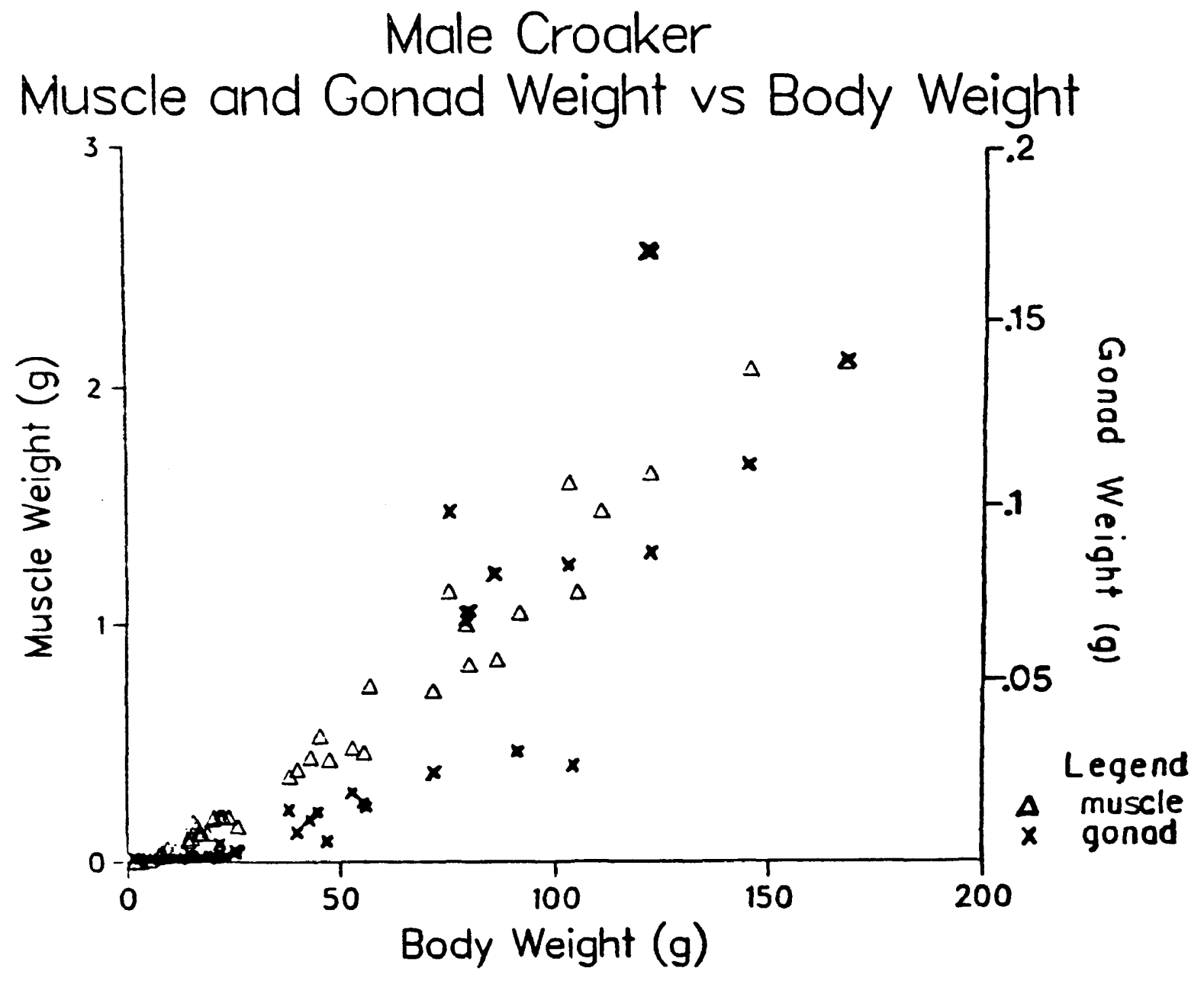


FIGURE 5. Regression of sonic muscle and gonad weight against body weight in female croaker. 


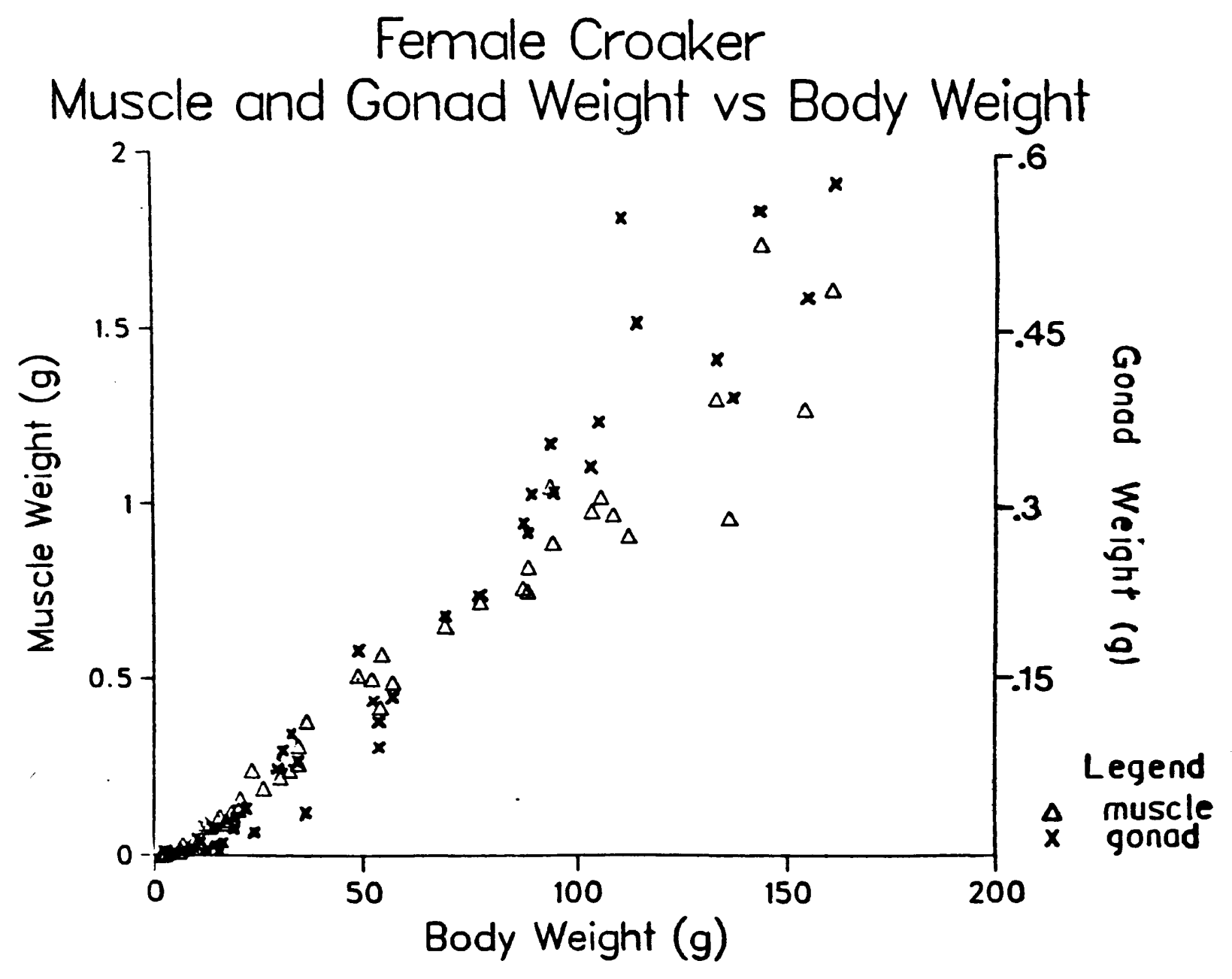


FIGURE 6. (A)Photomicrograph of cross section of immature testis in 109 mm S.L. male croaker; 525X. (B)Photomicrograph of cross section of developing testis in $182 \mathrm{~mm}$ S.L. male croaker showing active spermatogenesis (arrows show areas of spermatogenes is; $740 \mathrm{X}$ ) 

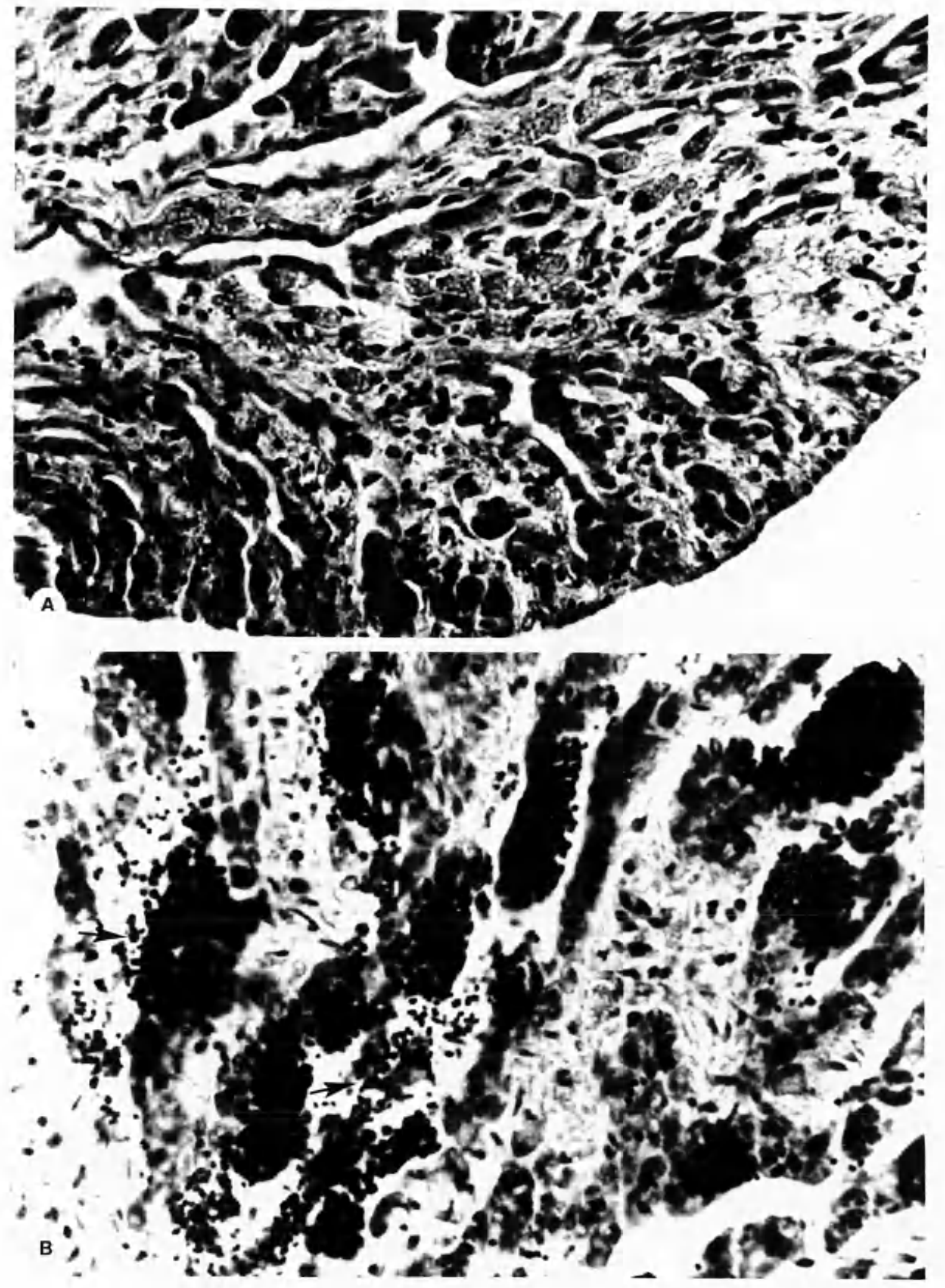
FIGURE 7. (A)Photomicrograph of cross section of immature ovary in 93 mm S.L. female croaker; 470X. (B)Photomicrograph of cross section of developing ovary in $188 \mathrm{~mm} \mathrm{~S} . \mathrm{L}$. female croaker showing early stage of gametogenesis (arrows show 2 ova in later stage of maturation; 470X). 

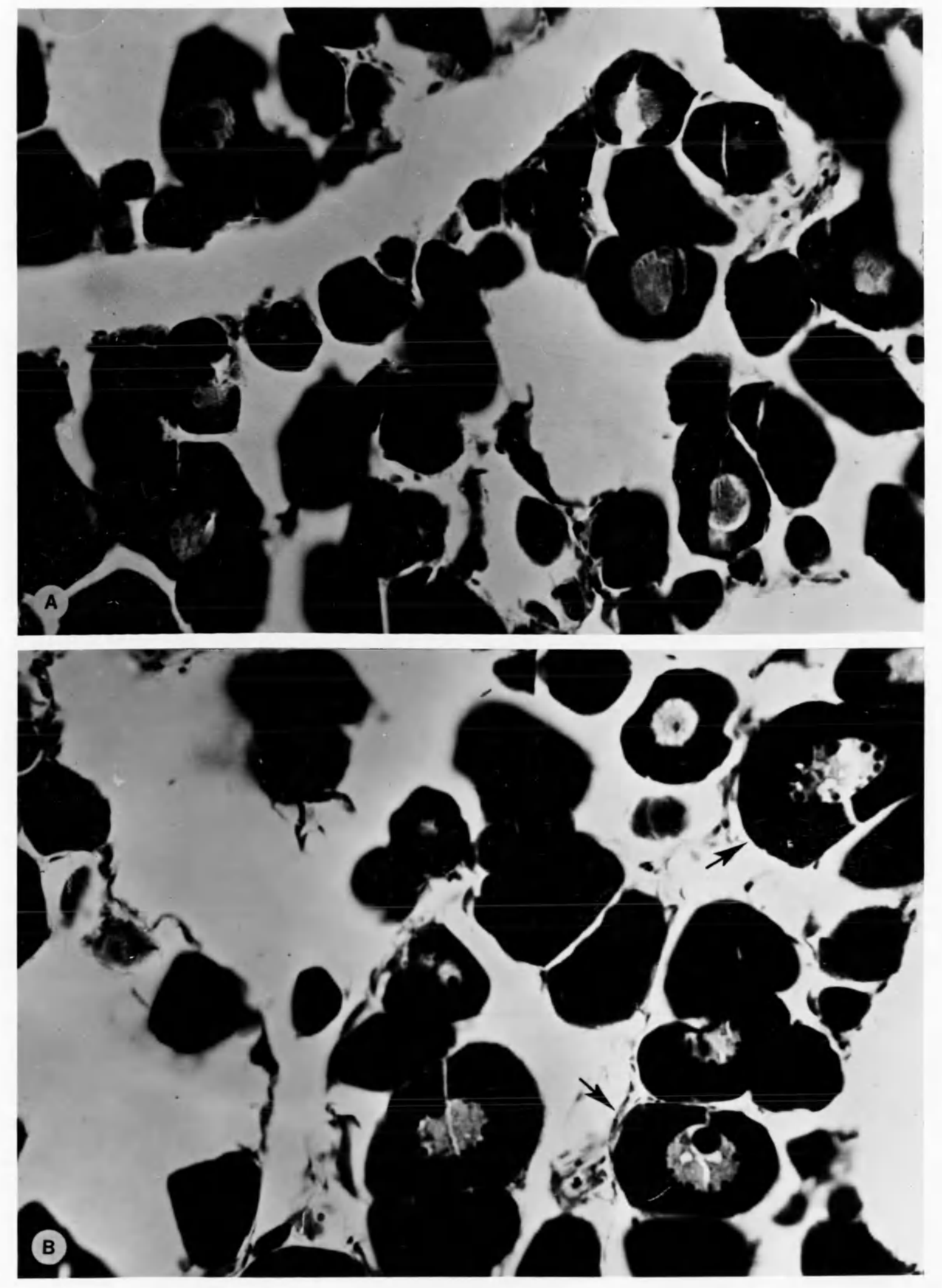
FIGURE 8. Regression of swimbladder weight against body weight for male and female croaker. 


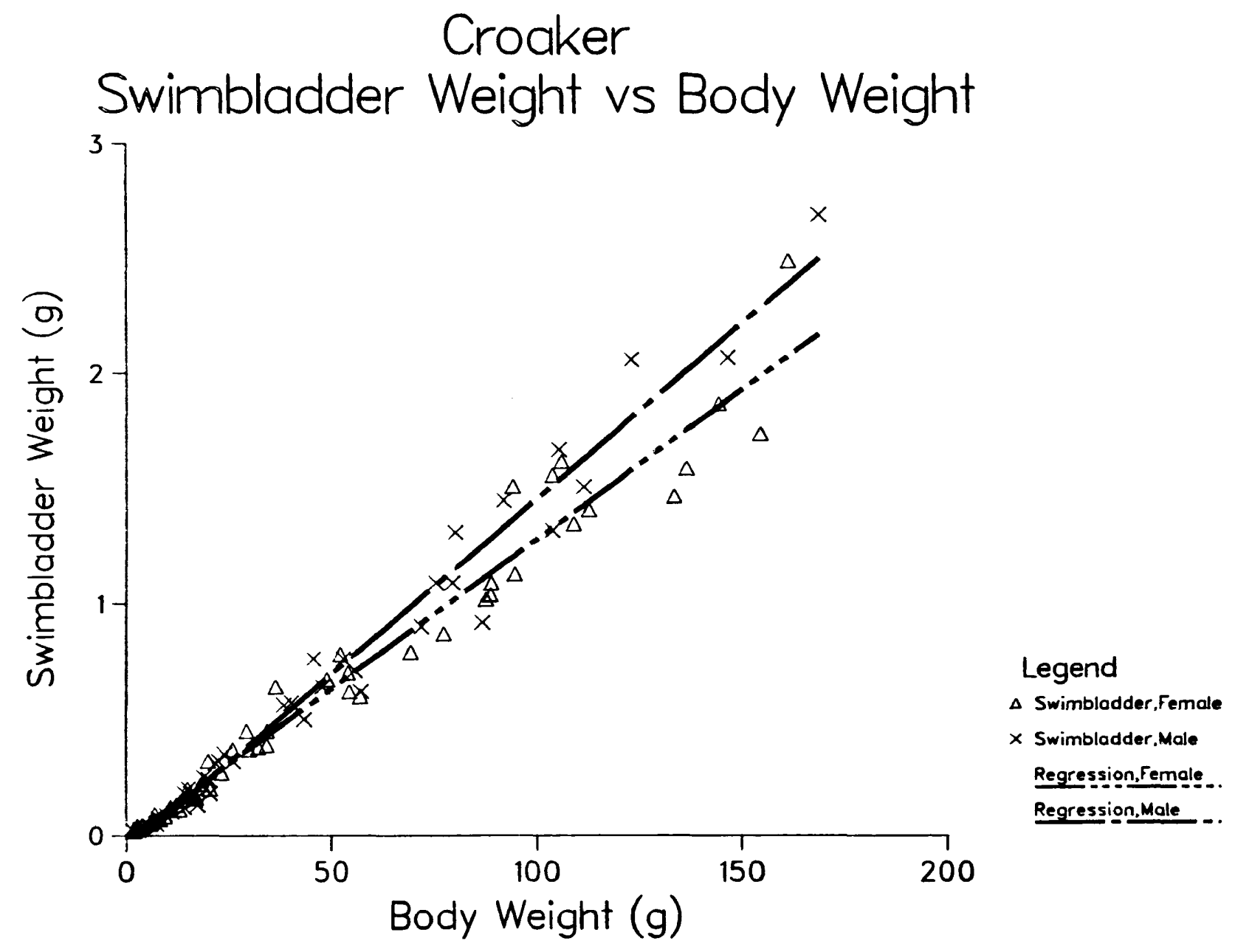


Spot

Twenty-seven male and thirty-one female spot were collected between the months of April and August, 1984. Numbers of individuals were low due to difficulties in catching males; several trawl catches consisted only of females. Eight males (ranging from $90-117 \mathrm{~mm}$ S.L.) possessed no visible sonic muscle tissue. In addition, sonic muscle was not observed in ten male specimens, all below $100 \mathrm{~mm}$ S.L., examined in a previous pilot study. The smallest individual collected with sonic muscle was $106 \mathrm{~mm} \mathrm{S.L.} \mathrm{with} \mathrm{a} \mathrm{muscle} \mathrm{weight} \mathrm{of} 2.9 \mathrm{mg}$. Ten fish between 108 and $118 \mathrm{~mm}$ S.L. were in early stages of sonic muscle development, with muscle weights of $6.5 \mathrm{mg}$ to $7.6 \mathrm{mg}$ (Appendix B). Weight of the sonic muscle increased linearly with body weight from this initial point (Fig. 9; Table 1). Equation of best fit 1 ine for spot was: Muscle weight $=-0.0722+0.0023$ (Body weight). The largest fish examined was caught in July and was $165 \mathrm{~mm} \mathrm{~S} . \mathrm{L}$. with a swimbladder muscle weight of $210.0 \mathrm{mg}$. Lengths and widths of muscle tissue are presented in Appendix B. Spot sonic muscle was consistently thinner and lighter in weight than in croaker or weakfish.

The initiation of sonic muscle growth and of increased growth of the gonads occured when spot were approximately $30.9 \mathrm{~g}$ (Fig. 11.) and there was a significant correlation between gonad growth and growth of the sonic muscle $\left(R^{2}=0.702\right)$. As gonads developed, sonic muscle growth was initiated. From this point on, growth of the sonic muscle coincided with development of the gonads. Gonadal tissue from one of the largest males (158 mm S.L.) was examined and found to be immature: 
undifferentiated spermatagonia were present, but spermatogenes is was not yet occuring (Fig. 12). No mature male spot were captured.

Swimbladder weight increased as a linear function of body weight for males and females (Fig. 13; Table 1), and there was no statistical difference between the regressions for each $\operatorname{sex}(F=2.7333$; $d f=1,51$; $p=0.1044)$. Equation of best $f$ it line for females was: Swimbladder weight $=0.0516+0.0036($ Body weight $)$; and for males was: Swimbladder weight $=0.0079+0.0047($ Body weight $)$. 
FIGURE 9. Regression of sonic muscle weight against body weight in spot. 


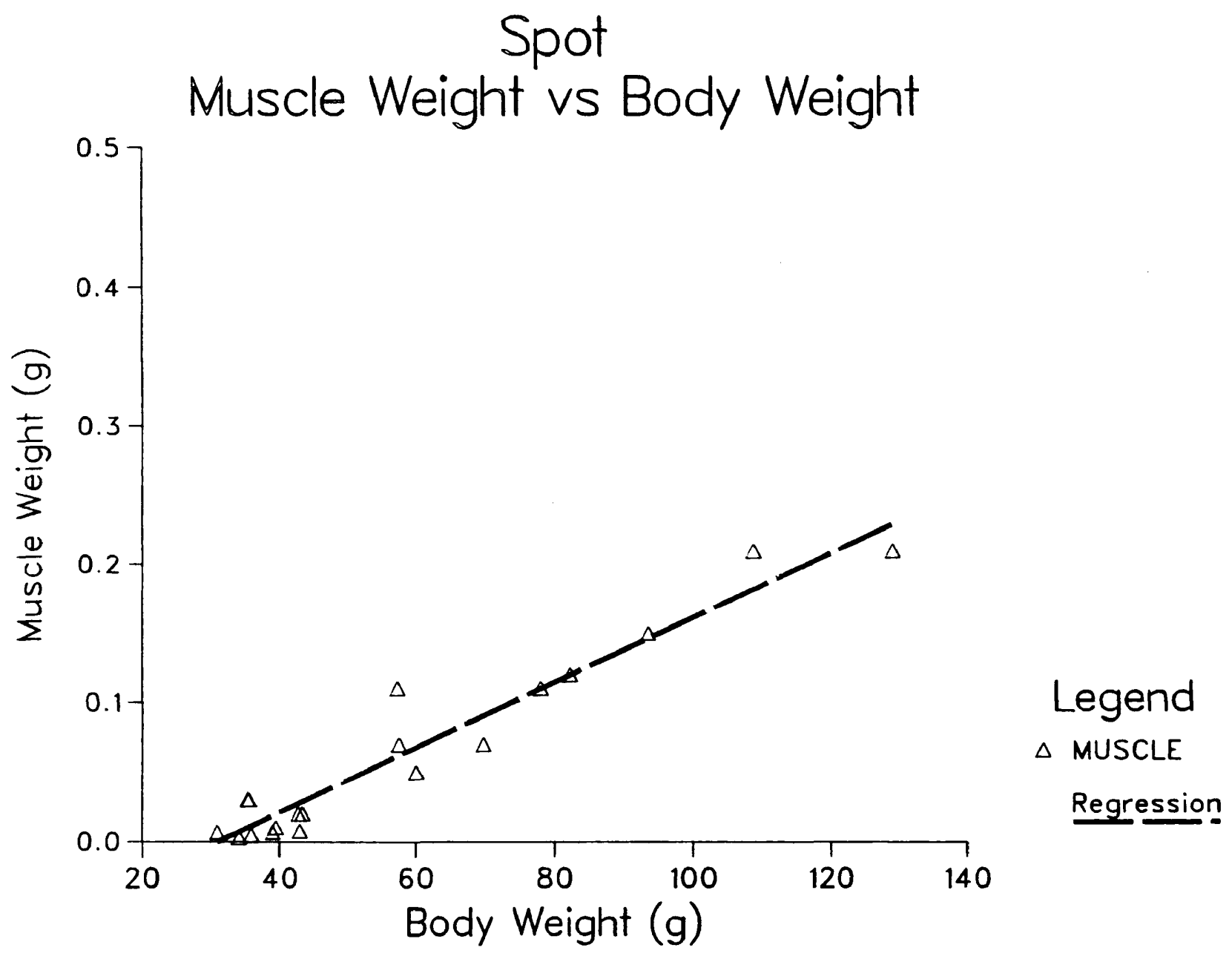


FIGURE 10. Regression of body weight against standard length in spot. 


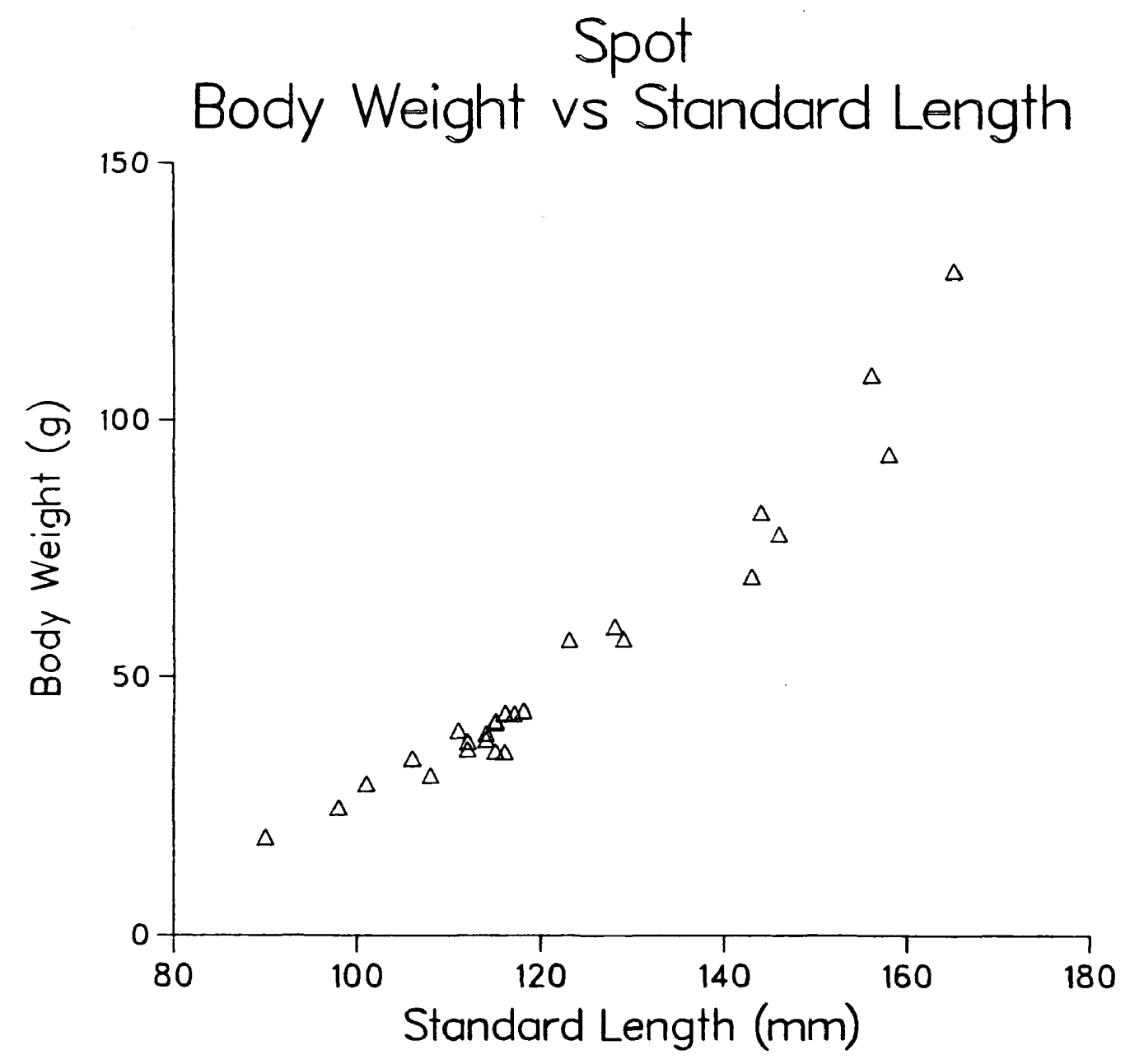


FIGURE 11 Regression of sonic muscle weight and gonad weight against body weight in spot. 


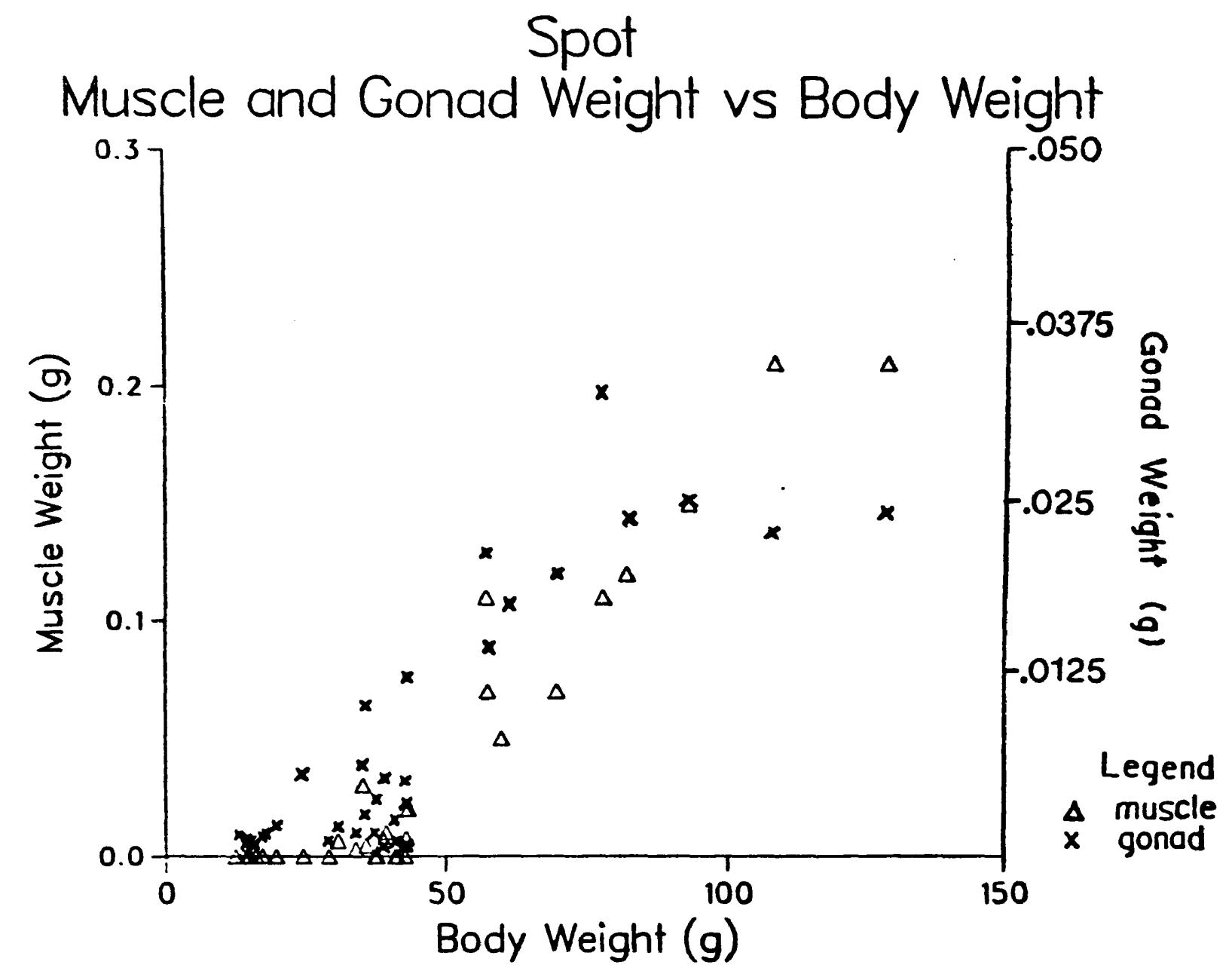


FIGURE 12. Photomicrograph of longitudinal section of immature testis in $158 \mathrm{~mm}$ S.L. male spot; 470x. 


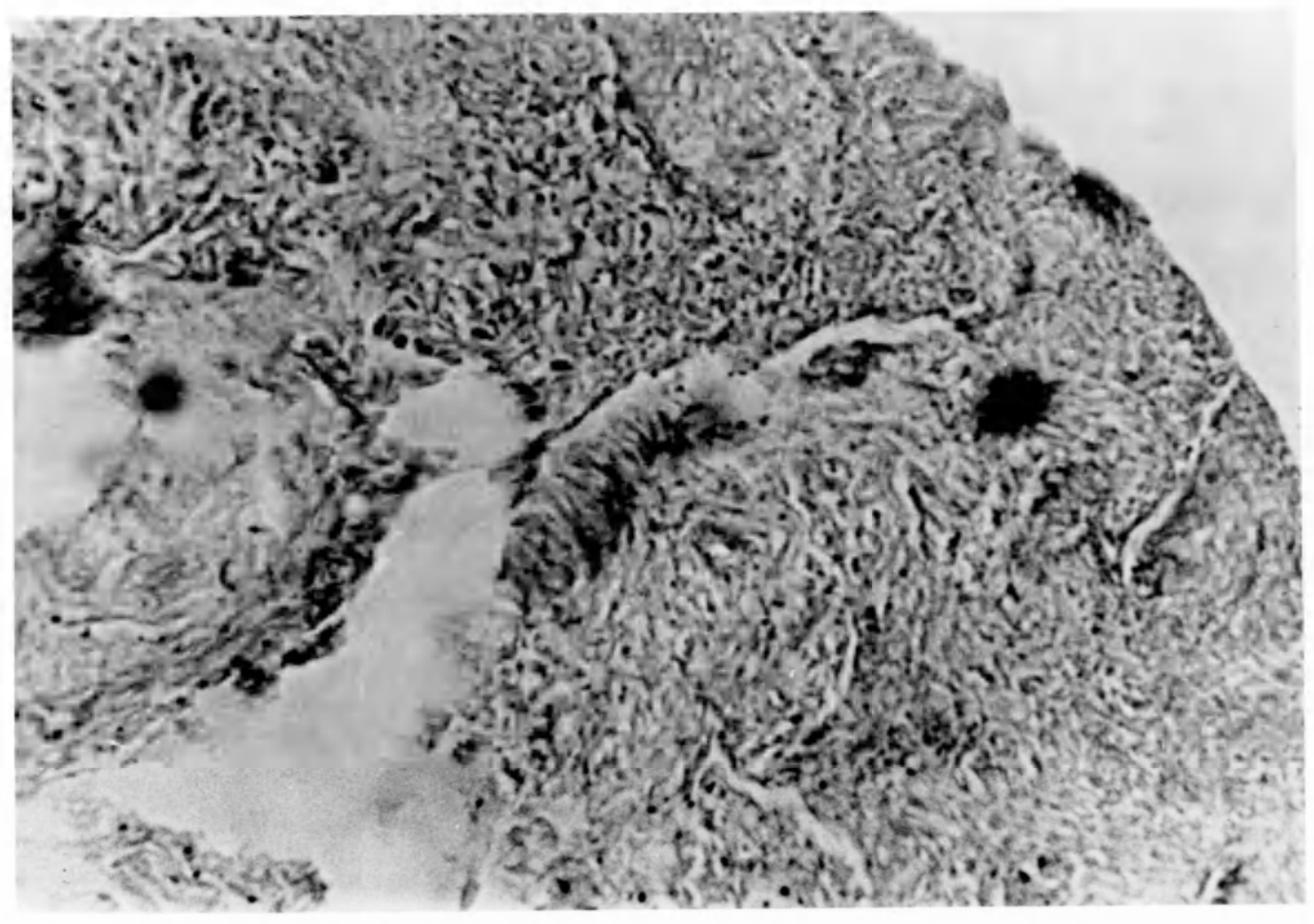


FIGURE 13. Regression of swimbladder weight against body weight for male and female spot. 


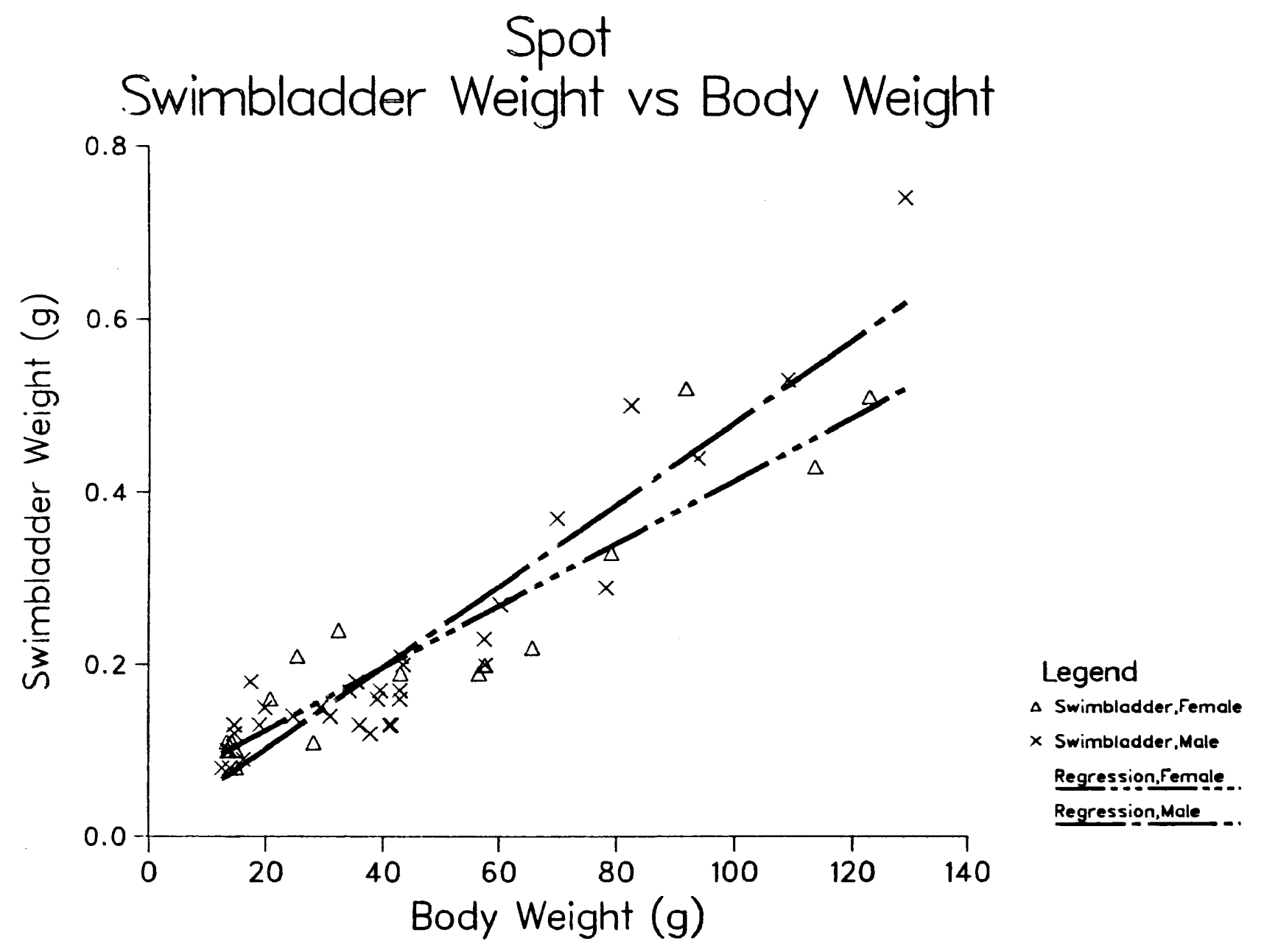




\section{Weakfish}

Twenty-three male and sixteen female weakfish were collected between the months of June and August, 1984. Numbers of male specimens were again low due to their absence in areas surveyed. No sonic muscle was observed in two males of 126 and $129 \mathrm{~mm} \mathrm{S.L.} \mathrm{The} \mathrm{smallest}$ individual with sonic muscle was $119 \mathrm{~mm}$ S.L. with a sonic muscle weight of $7.7 \mathrm{mg}$ (Appendix C). Sonic muscle weight increased linearly with body weight from this initial point (Fig. 14; Table 1). Equation of best $f$ it line for weakfish was: Muscle weight $=-0.5245+0.0162$ (Body weight). The largest male examined, $182 \mathrm{~mm}$ S.L., had a sonic muscle weight of $870.0 \mathrm{mg}$, though a slightly smaller individual at $179 \mathrm{~mm}$ S.L. possessed a sonic muscle of $1630.0 \mathrm{mg}$. Lengths and widths of muscle tissue are presented in Appendix C.

As in croaker and spot, the initiation of sonic muscle development and the acceleration of gonad growth began at approximately the same weight (Fig. 16) and there was a significant correlation between gonad growth and sonic muscle growth $\left(R^{2}=0.909\right)$. Muscle tissue was first observed at $29.6 \mathrm{~g}$ in weakfish. At this same weight, growth of the gonads began to increase steadily. From this point on gonad development remained synchronous with muscle development. Gonadal tissue were examined in two of the males. In the smallest individual caught (119 mm S.L.), histological sections with primary and secondary spermatocytes present demonstrated that spermatogenes is was just beginning (Fig. 17-1;17-2). Muscle development occured at approximately the same time as the onset of spermatogenesis (Table 2). 
A larger male of $148 \mathrm{~mm}$ S.L. showed active spermatogenes is with spermatazoa present (Fig, 18).

Swimbladder weight increased as a function of body weight for males and females (Fig. 19; Table 1), and there was no statistical difference between the regressions for each $\operatorname{sex}(F=0.0096 ; d f=1,37$; $p=0.9221)$. Equation of best $f$ it line for females was: Swimbladder weight $=-0.1874+0.0255$ (Body weight); and for males was: Swimbladder weight $=-0.1619+0.0251($ Body weight $)$. 
FIGURE 14. Regression of sonic muscle weight against body weight in weakfish . 


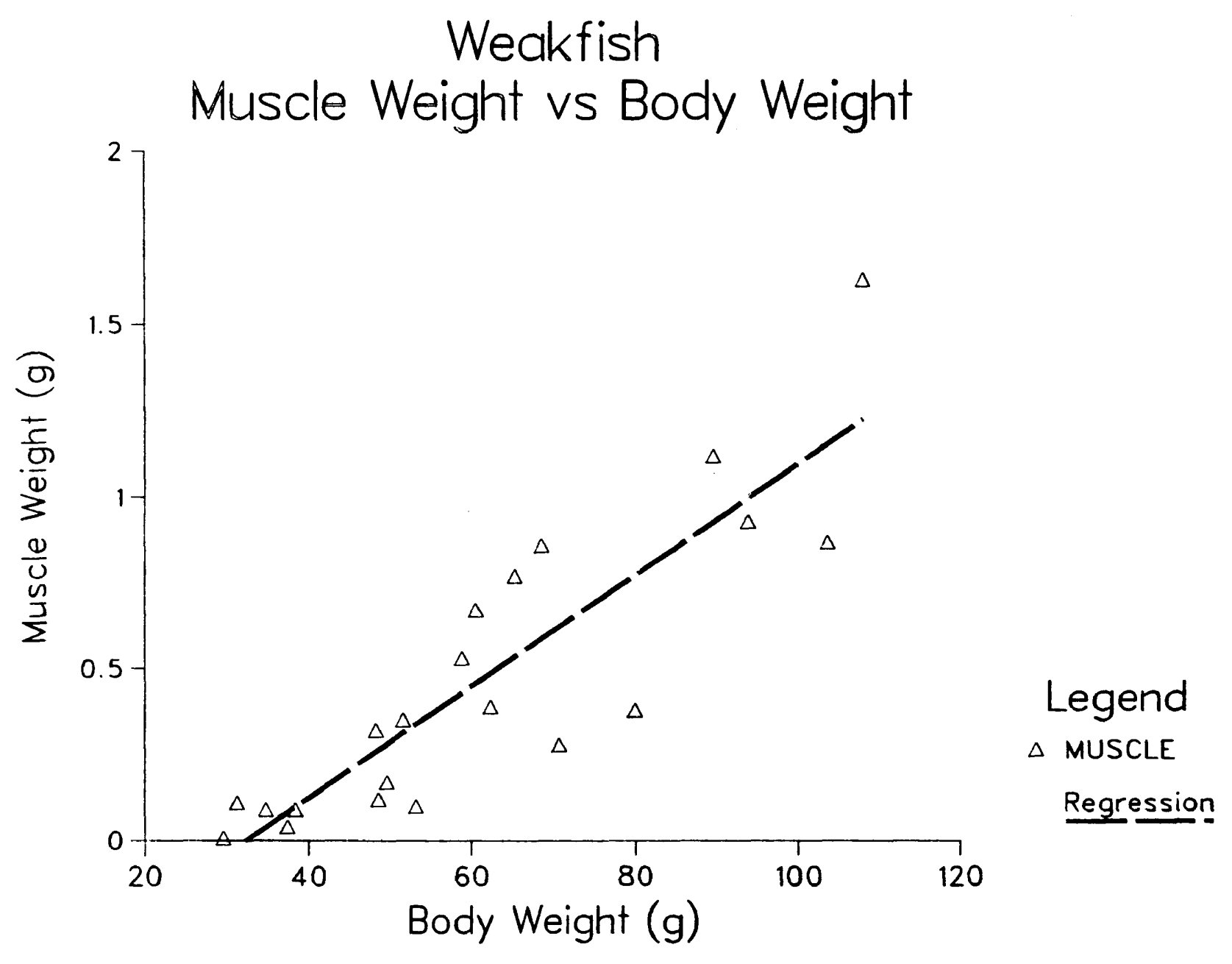


FIGURE 15. Regression of body weight against standard length in weakfish. 


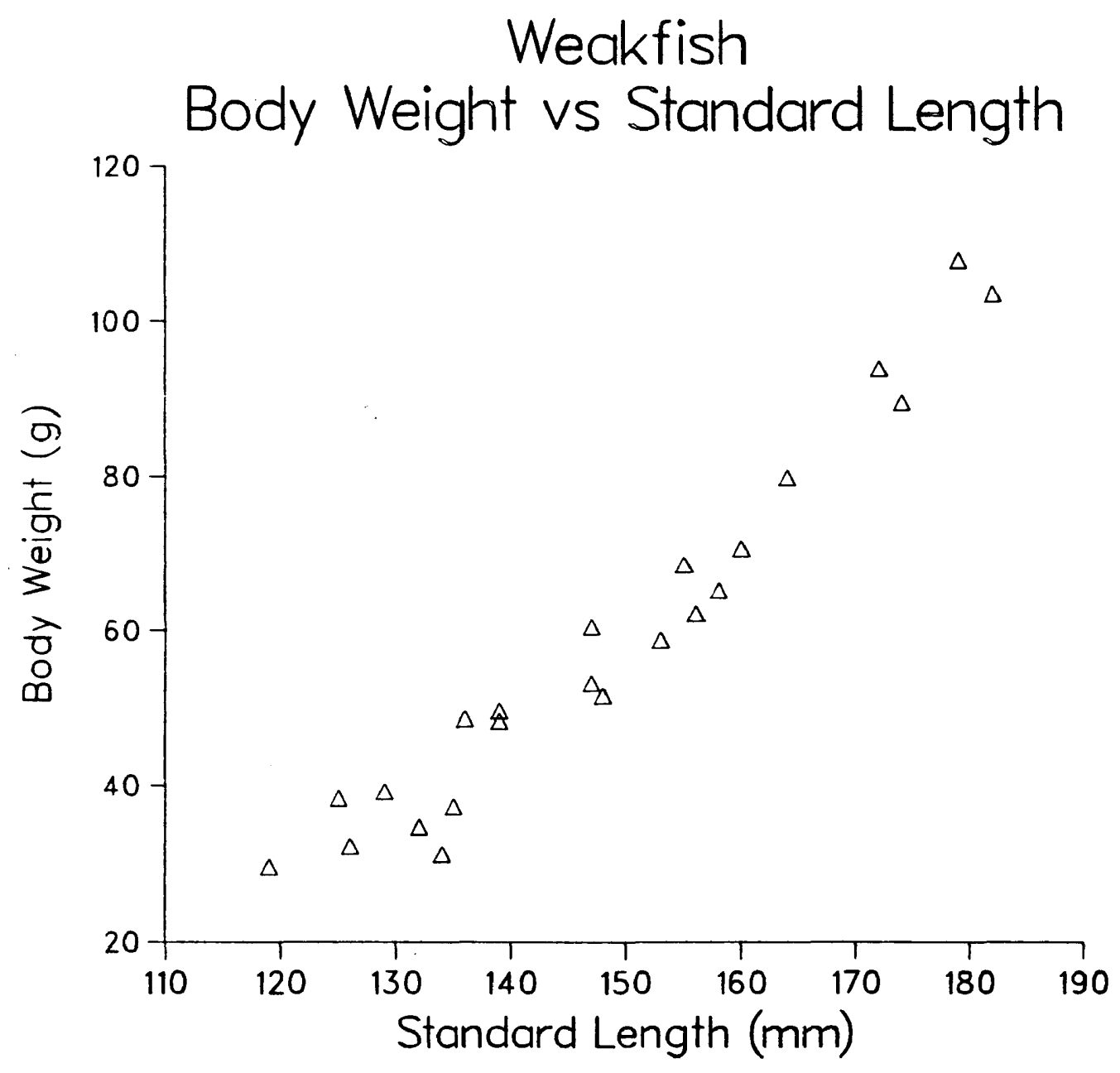


FIGURE 16. Regression of sonic muscle weight and gonad weight against body weight in weakfish. 


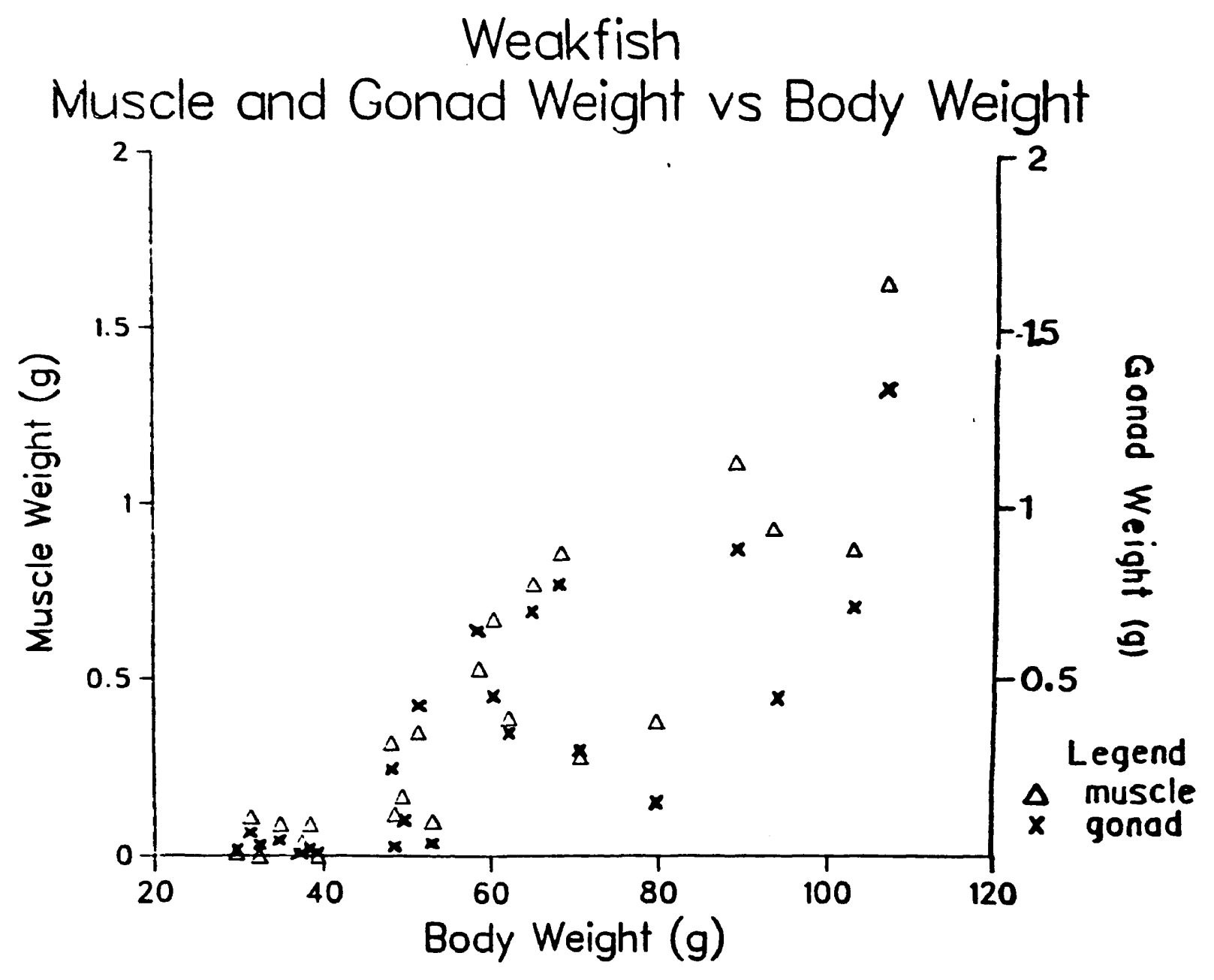


FIGURE 17. (A)Photomicrograph of cross section of developing testis in $119 \mathrm{~mm}$ S.L. male weakfish; 945X. (B)Photomicrograph of cross section of developing testis in same specimen showing area undergoing early stage of spermatogenesis; 1285X). 


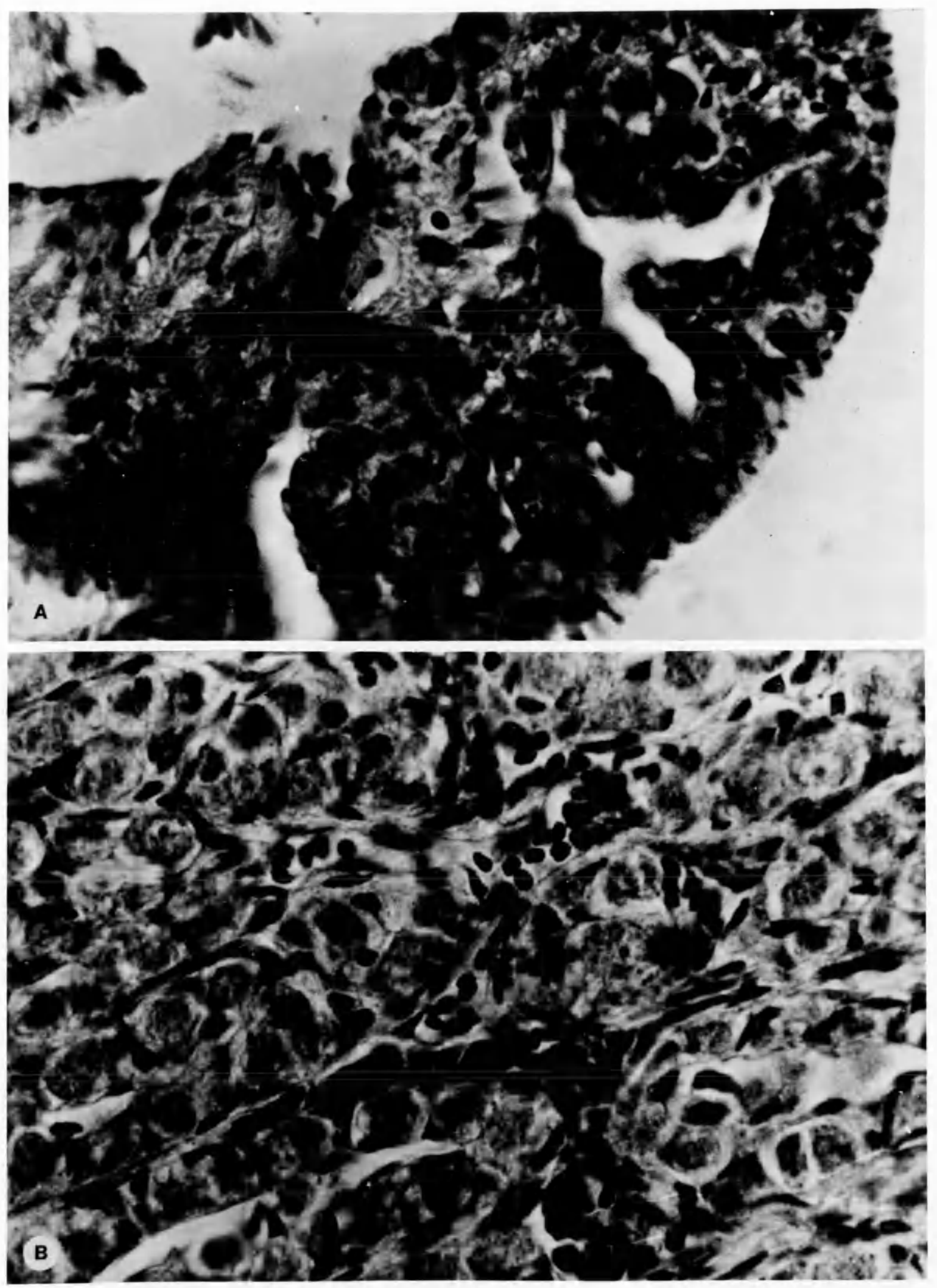


FIGURE 18. Photomicrograph of cross section of developing testis in 148 $\mathrm{mm}$ S.L. male weakfish undergoing active spermatogenesis. Arrows show several stages of spermatazoa are present (magnification $=768 \mathrm{X})$. 


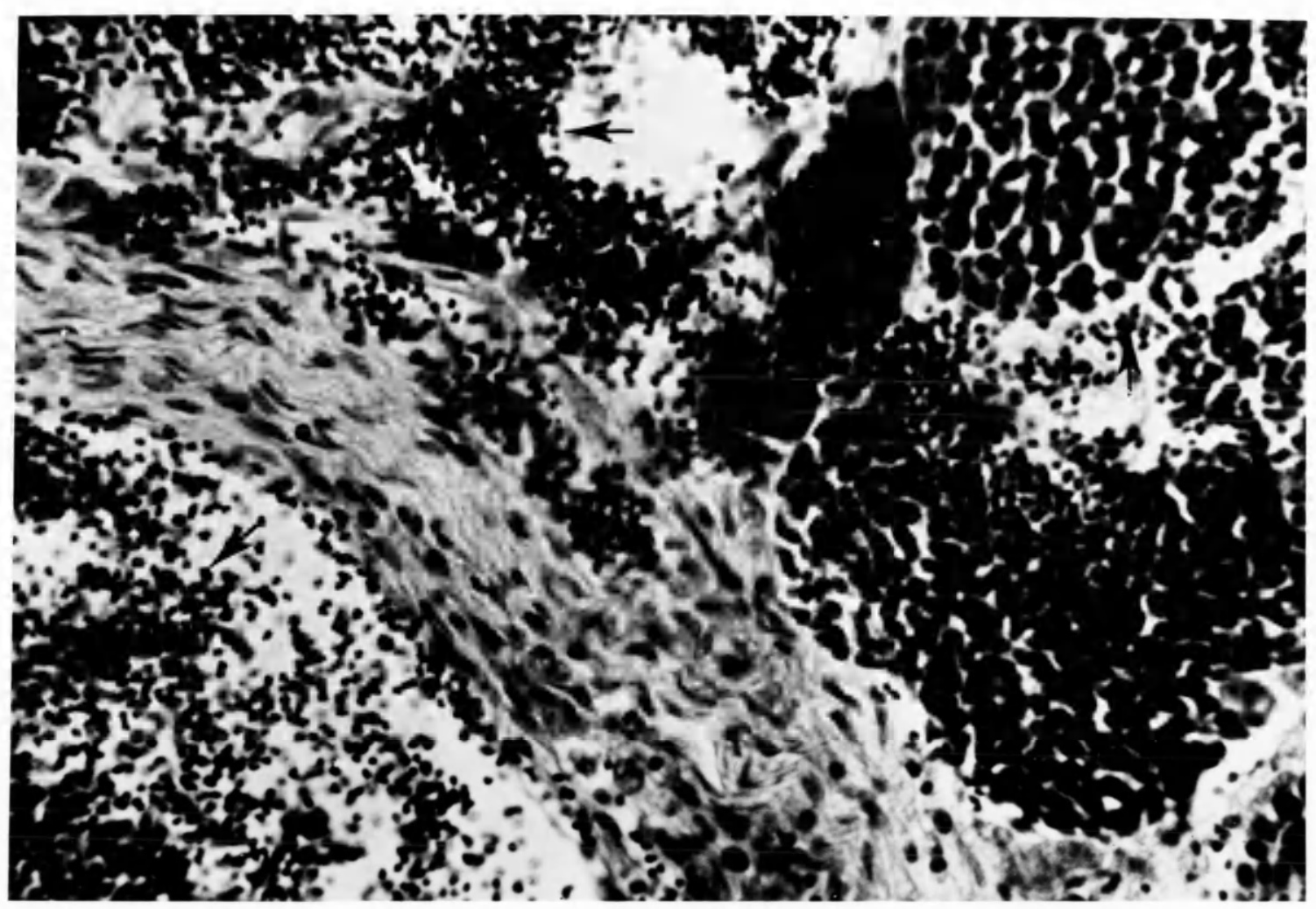


FIGURE 19. Regression of swimbladder weight against body weight for male and female weakfish. 


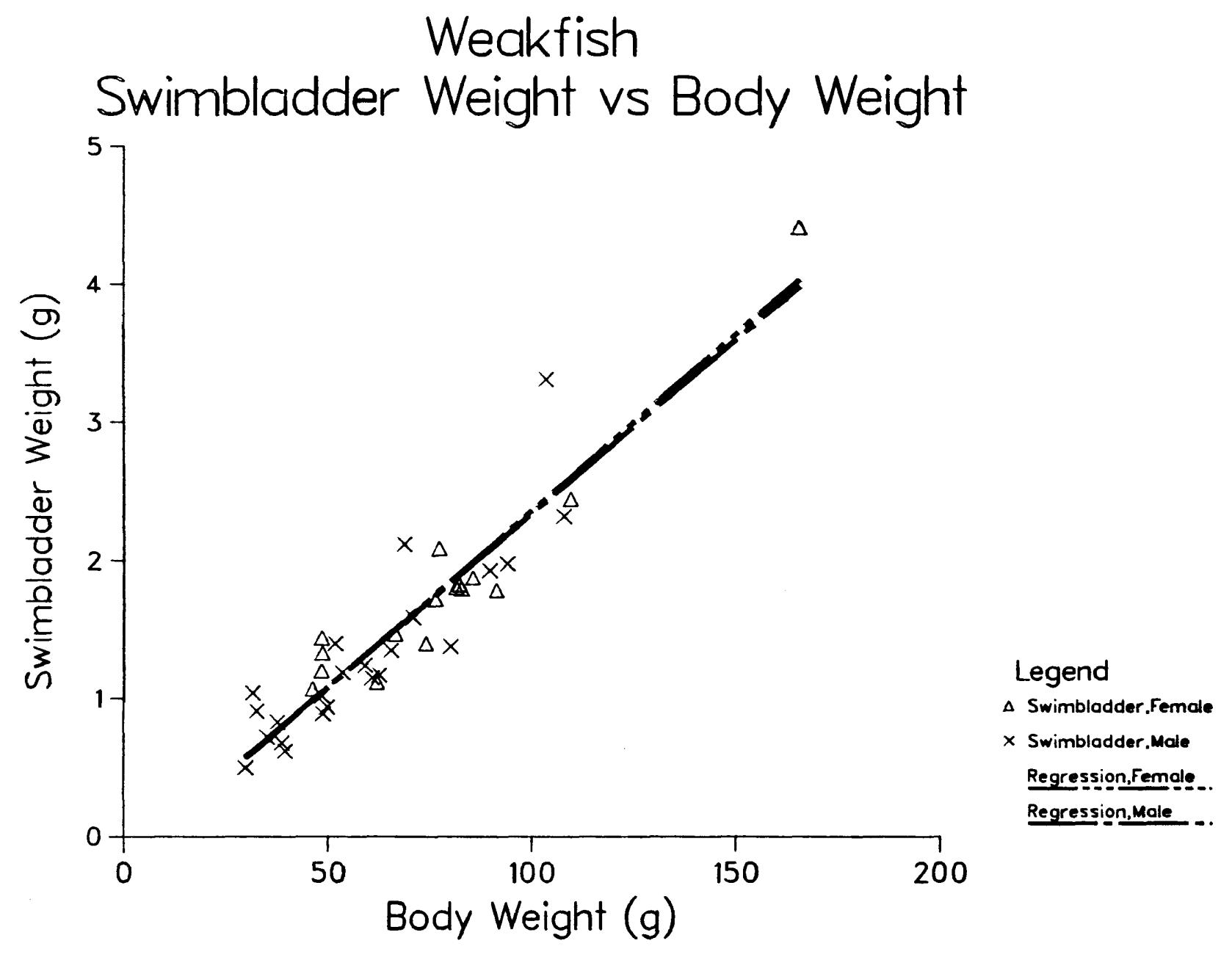




\section{Discussion}

Development of the sonic muscle in sciaenids can occur either through normal somatic growth or as a secondary sex character under the direct control of steroids. Of the two possible pathways, development under steroidal control seems the most likely. Fine and Pennypacker (in preparation) have shown that steroids cause an increase in the weight of the swimbladder and sonic muscles in toadfish. Males and females show significant treatment effects. Though toadfish sonic muscles form embryologically and are fully attached by the time the larvae are free swiming (Tracy, 1959, 1961), the tissues are responsive to steroids suggesting that the dimorphic condition of adults is a result of male hormone levels. In the present study, the first appearance of the sonic muscle occured when the fish were from 4 to 5 months old in croaker, 6 to 7 months old in spot and 11 months old in weakfish, and at sizes ranging from $45 \mathrm{~mm} S . L$. in croaker to over $100 \mathrm{~mm} \mathrm{S.L.} \mathrm{in} \mathrm{spot} \mathrm{and} \mathrm{weakfish.} \mathrm{Initiation} \mathrm{of} \mathrm{sonic} \mathrm{muscle}$ growth, then, took place after several months of development which suggests hormonal interaction. Further, in all three species, muscle development was concurrent with accelerated growth of the gonads. Sonic muscle development was nonexistent at weights below the point where gonads began to increase. As the rate of gonad growth became greater, however, sonic muscle development was initiated. The implication is

that the sonic muscle develops as a secondary sex character, apparently forming de novo and growing in synchrony with the gonads. Development 
of the sonic muscle would begin as muscle precursers are stimulated through the release of steroids. Though development of the muscle in my study occured before full maturity (coincidentally in weakfish), differentiated areas of the gonad, such as the interstitial cells, have been implicated in steroidogenic activity (Oota and Yamamoto, 1966; Takahashi and Iwasaki, 1973; Satoh, 1974; Van Den Hurk, 1974; Nagahama et a1., 1978; Van Den Hurk et a1., 1982;) and may be responsible for initiation of sonic muscle growth and the sex differences noted. Growth of the muscle would proceed under the controlling effects of gonadal steroids.

Swimbladder weight also varied sexually in croaker with male swimbladders heavier than females. Because selection pressures for the evolution of the swimbladder involve sound production, hearing, and hydrostatic functions, it is difficult to attribute relative size to any one factor. However, differences between swimbladders in male and female croaker may reflect a compensation for the larger sonic muscles in the male, since there were no sexual differences in swimbladder size in spot or weakfish. The sexually dimorphic condition of the croaker sonic muscle, however, is undoubtedly related to sound production. One might predict that males call more frequently, more intensely and produce a lower dominant frequency sound than females.

\section{Croaker}

Spawning in Atlantic croaker occurs over a protracted period extending at least from September to late March with a distinct peak 
around October (White and Chittenden, 1977). The spawning season may begin as early as August or July in some areas as Chao and Muscick (1977) observed young of the year first entering trawl and beach seine catches in August in the York River. Pearson (1941) found young of the year near the mouth of the Chesapeake Bay in late July ranging from 1.5 to $15 \mathrm{~mm}$, indicating either the presence of early spawners or that the breeding season may extend later than March. Offshore spawning grounds are unknown though some spawning occurs around the mouth of the Chesapeake Bay (Pearson, 1929). Atlantic croaker spawn in the Mid At lantic Bight from Cape May, N.J. to Cape Hatteras, N.C. with greatest concentrations in the middle and southern parts of this range (Norcross, 1983).

A variety of data exists concerning length and age at sexual maturity in croaker (Table 2). Wallace (1940) examined almost 1000 gonads from fish of various ages in Chesapeake Bay and found that only $45 \%$ of males reach maturity at the end of their second year and that no females at this age give signs of ripening. By the third year, all males and females are mature. The smallest mature male and female croaker are $240 \mathrm{~mm}$ in total length (T.L.) ( 2 years old) and $275 \mathrm{~mm}$ T.L. (3years old) respectively. Pearson (1929), in studying length distribution in Texas croaker, reported a total length of about $150 \mathrm{~mm}$ reached by the end of the first year, extending up to $220 \mathrm{~mm}$ T.L. by the end of the second year. In further observations, he notes the length distribution of 230 sexually mature individuals. Mature males range from $140 \mathrm{~mm}$ to $320 \mathrm{~mm}$ T.L. with mature females occuring over a 
similar, though higher, range of $150 \mathrm{~mm}$ to $370 \mathrm{~mm}$ T.L. The modal length for the entire group of males and females is $220 \mathrm{~mm} T . \mathrm{L}$. which corresponds to fish at the end of their second year. Thus, the majority mature near the end of the second year though some reach maturity earlier. This data is not necessarily contradictory to Wallace's findings on croaker in Chesapeake Bay that the fish reach maturity at the end of their second or third year since Chabanand (1929) and Hildebrand and Cable (1930) suggested that individuals of the same species may mature at an earlier age in warmer climates (Wa1lace, 1940). White and Chittenden (1977) reached a similar conclusion observing that while croaker started to mature at $140-170$ mm T.L. in the Gulf of Mexico, fish living north of Cape Hatteras reached maturity when greater than $200 \mathrm{~mm}$ T.L. as they approached age 2.

Croaker sonic muscle first appeared at about $45 \mathrm{~mm}$ S.L., which corresponds to approximately 4 to 5 months of age in both males and females (Welsh and Breeder, 1923; Hildebrand and Cable, 1930; Parker, 1971). Because of the extended spawning season it is difficult to give a specific age. Devlopment of the sonic muscle, though, began long before the gonads approached maturity. But muscle development proceeded together with the initiation of increased growth of the gonads. This may be more important since gonad tissue is capable of steroid production before sexual maturity, which could initiate muscle development. The sonic muscle of individual male and female croaker taken below $60 \mathrm{~g}$ were roughly equal with respect to size and weight of 
the muscle tissue. Above $60 \mathrm{~g}$ male sonic muscle increased in weight at a faster rate than female muscle. This difference was more pronounced as croaker increased in size so that muscle tissue of males became visibly thicker in size and larger in length and width. Sexual differences in sonic muscle at these larger body weights may be related to level of sexual maturity, assuming differences in steroid production between mature males and females.

Spot

Spawning in Atlantic spot may occur from October to March with December and January generally accepted as the spawning months (Dawson, 1958). This appears consistent with other reports. Chao and Musick (1977) observed that yearling or older spot leave the estuary after September and do not return until spring of the next year. Hildebrand and Schroeder (1928) reported offshore migration of maturing fish from September to October. Offshore data show ripe or nearly ripe fish taken during October, December, and February, with spent fish occuring in catches in February (Dawson, 1958). Spawning is believed to occur in deep water some distance offshore.

Studies on spot have revealed the size and age over which sexual maturity is reached (Table 2). Hildebrand and Cable (1930) observed no spot less than 8 in. (203 mm T.L.) with developing or nearly mature roe. At Alligator Harbor, Florida, Townshend (1956) examined the gonads of 56 spot and found the earliest development occuring at a standard length of $149 \mathrm{~mm}$. He estimated that spot did not spawn until 
their second winter or the beginning of the third year. Hildebrand and Schroeder (1928) found developing roe in $214 \mathrm{~mm}$ T.L. fish and stated that no fish less than $81 / 2$ in. $(215 \mathrm{~mm})$ in total length contained gonads mature enough to spawn that year. Pearson (1929) found ripening adults ranging from $170-210 \mathrm{~mm}$ T.L. - lengths attained in the second year. Noting that few Texas spot reach over two years in age, he postulated that most spawning took place at the end of the second year. In each study of sexual maturity, lengths and age at maturity were much greater than the range over which the sonic muscle began to develop. Maturation of the gonads occurs at lengths ranging from $149 \mathrm{~mm}$ S.L. to $215 \mathrm{~mm}$ T.L. and at ages of from two to three years. I observed the first appearance of sonic muscle in $\mathrm{fish}$ that were approximately 6 to 7 months old (Hildebrand and Cable, 1930; Pacheco, 1957; Parker, 1971). Hildebrand and Cable (1930) examined spot off the Beaufort, North Carolina coast and found an average length of 5.6 in. T.L. (139.3 $\mathrm{mm}$ ) attained by the end of the first year. Further, in studying the size range of Texas spot, Pearson (1929) found an average length of 140 mon T.L. by the end of the first year. Even taking into account differences between standard and total length, one still finds that the size over which muscle tissue first appeared in western North At lantic spot occured during the first year of growth. While maturation of the gonads has been shown in various studies to occur from two to three years of age, muscle development occured in fish of one year of age which were not yet fully mature. Though occuring before full maturation, sonic muscle development does proceed in synchrony with the 
acceleration of gonad growth. Thus the initiation of muscle growth is directly related to development of the gonads.

Weakfish

The spawning season of weakfish is an extended one as in croaker and spot, occuring from late April through June as indicated by gonad condition (Merriner, 1976) and possibly extending to October (Welsh and Breeder, 1923). Females appear to spawn the major portion of eggs in May or June with a second, smaller spawning possibly occuring in late July or August (Merriner, 1976). Fertilized eggs are pelagic and larvae disperse to nursery grounds soon after hatching. Young of the year first entered trawl catches of the York River in July or August (Chao and Musick, 1977). Weakfish move offshore to spawn but are also found spawning in Pamlico Sound, North Carolina (Merriner, 1976). Thus, spawning may occur in sounds and bays as we11 as offshore these areas being at the edge of the spawning zone (Merriner, 1976). The youngest weakfish collected in this study (approximately 119 mm) was approximately 11 months old assuming spawning occured in June (Merriner, 1976). In a summary of published data concerning $\underline{\mathbf{C}}$. regalis, Wilk (1978) listed a range of 130 - $315 \mathrm{~mm}$ T.L. for growth of weakfish at the end of the first year. Based on Wilk's compiled data, my collection of weakfish were either approaching the end of their first year or were one year of age.

Merriner (1976), in a comprehensive study of weakfish off the coast of North Carolina, found sexually mature fish at one year of age 
with some of the smaller individuals maturing at two years (Table 2). To determine maturity, the standard length range in which $50 \%$ of weakfish are classified as mature, ripe, or ripe running is considered the size at which sexual maturity is attained (Merriner, 1976). Using this criteria, male weakfish mature before females. In the Moorehead City area, males mature at $130 \mathrm{~mm}$ S.L and females at $145 \mathrm{~mm}$ S.L. Similarly, at Pamlico Sound, males mature first at $150 \mathrm{~mm}$ S.L. while females mature at $190 \mathrm{~mm} \mathrm{S.L.} \mathrm{Though} \mathrm{sexual} \mathrm{maturity} \mathrm{occurs} \mathrm{in} \mathrm{males}$ on average around $130-150 \mathrm{~mm}$ S.L., there were specimens collected by Merriner which matured earlier. Fish at $105 \mathrm{~mm} \mathrm{S.L.} \mathrm{and} \mathrm{several} \mathrm{at} 115$ m.L. are sexually mature.

One would expect weakfish to mature at a similar size range off the Virginia coast owing to a similar environment and seasonal component. Further, weakfish to the northward may move southward in winter for long distaces, and offshore, as some of the northward summering scup do (Bigelow and Schroeder, 1923). If this movement also occurs with respect to Chesapeake Bay weakfish, the population off the coast of North Carolina may be from the same population as those seen in the bay area during the summer months. In either case, Merriner's data is applicable to the data gathered during the present study. Merriner's $50 \%$ average size over which males are found to be sexually mature is greater than the size at which sonic muscle began to develop. However, maturity here is determined by the point at which $50 \%$ of the sample are fully mature. Thus, there are individuals who are immature, those who are only beginning the process of spermatogenesis, or have 
yet to attain full maturity, as well as individuals who mature well before the average. In a closer examination of Merriner's data one finds an example of $105 \mathrm{~mm}$ and several at $115 \mathrm{~mm} \mathrm{~S} . \mathrm{L}$. in which sexual maturity has already been reached. Thus, the smallest individual in the present study found to possess sonic muscle (119 mm S.L.) fell within the range over which spermatogenesis was taking place. In support of this, my data showed the initiation of muscle growth to be concurrent with increased growth of the gonads. As the rate of gonad development began to accelerate, then, the sonic muscle tissue began to appear.

Merriner (1976) observed an interesting phenomenon with weakfish which cannot be confirmed here due to a limited collection period. Drumming muscles begin enlarging in December for the next breeding season and recede in size after the breeding season. The changes in muscle size correlate with the ripe and spent condition of the gonads. 
TABLE 1. Presentation of statistical data calculated for each species. 


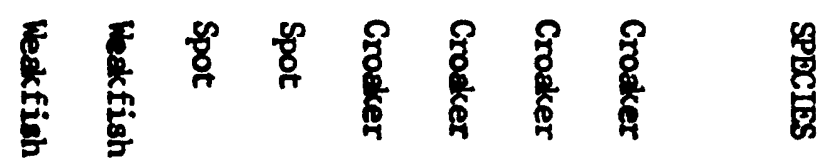

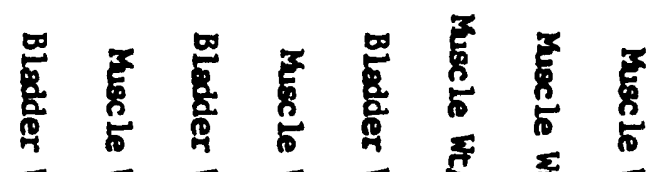

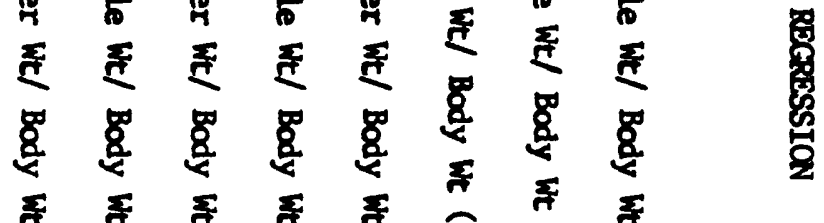

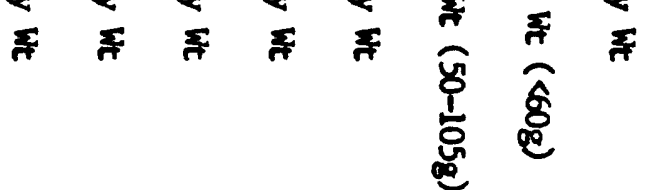

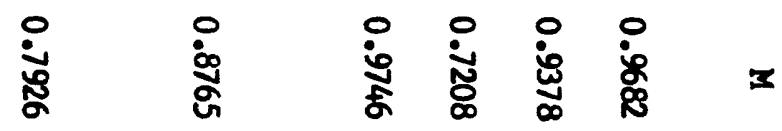

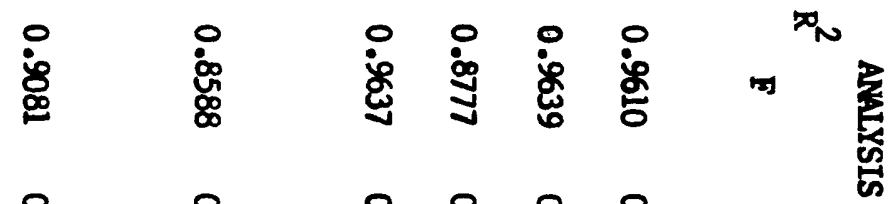

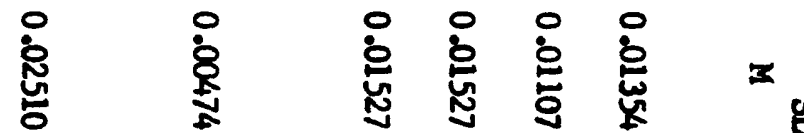

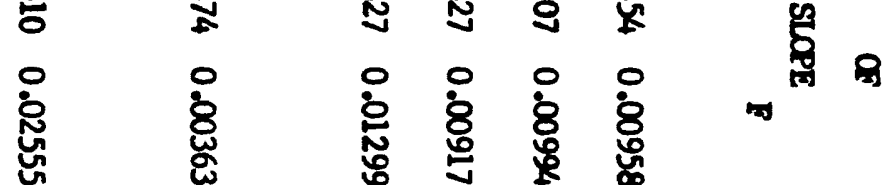

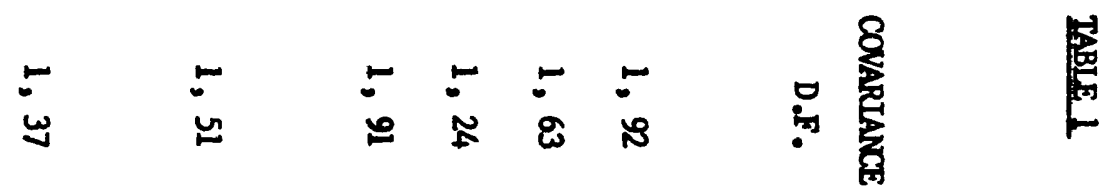

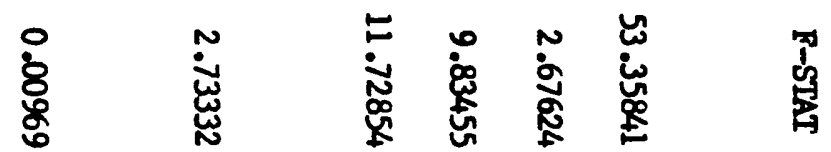

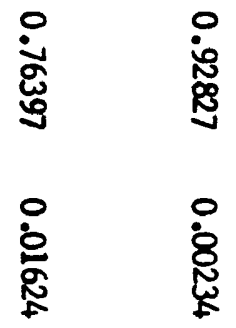

D

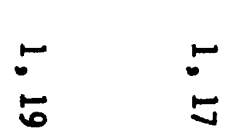

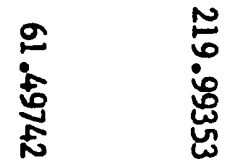

蛋

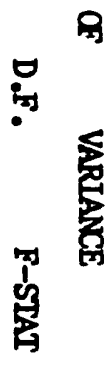


TABLE 2. Correlation of data on sexual maturity, muscle development, and spawning season. 
TABLE 2

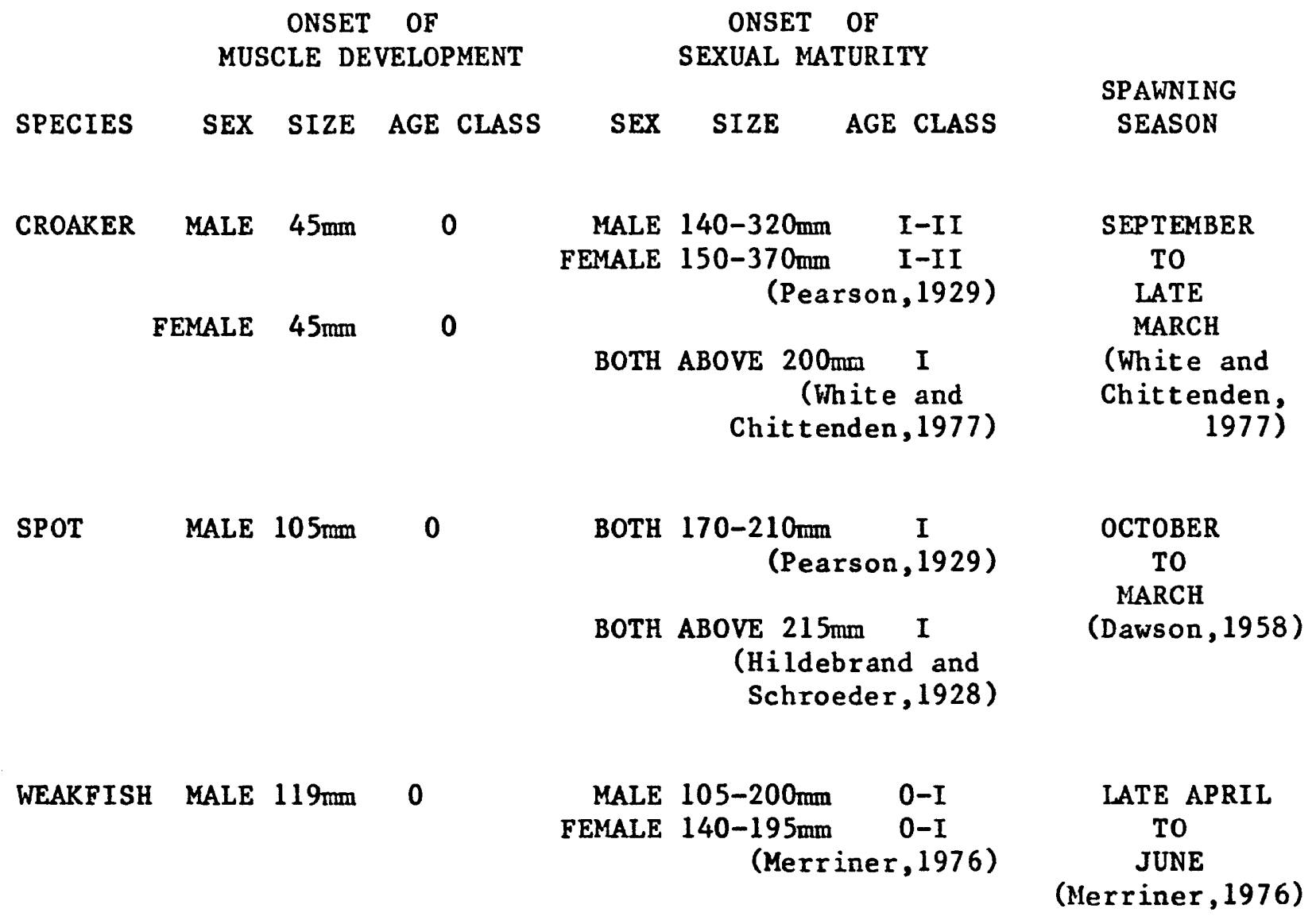


Summary and Conclusion

\section{Croaker}

The croaker presents a unique case in sciaenid fishes in that both male and female possess the sonic muscle. Development began at the same length and age in both sexes and occured long before sexual maturity was reached. Croaker mature at ages of two years or more and at lengths exceeding $200 \mathrm{~mm}$ T.L. according to Wallace (1940). Gonads examined in my study support this. Individuals at $93 \mathrm{~mm}$ and $109 \mathrm{~mm}$ S.L. were immature. However, a male at $184 \mathrm{~mm}$ S.L. was sexually mature and a female at $187 \mathrm{~mm}$ S.L., though not fully mature, was developing primary oocytes. Croaker sonic muscle, on the other hand, began to develop around $45 \mathrm{~mm}$ S.L. -- well within the first year. Though sonic muscle did develop before full maturation of the gonads, initiation of muscle growth coincided with the increased growth of the gonads. Thus, as the rate of gonad development increased, sonic muscle growth began. Male sonic muscle, however, began to grow larger than that of the female at $50 \mathrm{~g}(140-150 \mathrm{~mm}$ S.L.). This size difference in muscle, which is more highly exaggerated in larger individuals, may correlate with gonadal state of sexually mature individuals. This would indicate a connection (presumably hormonal) between the increased growth of the male muscle with increased development of the testes. 
Spot

Although only male spot possess the swimbladder muscle, the muscle itself appeared before gonadal spermatogenesis. Sexual maturity begins to appear around lengths of $149 \mathrm{~mm} \mathrm{S.L.} \mathrm{(Townshend,} \mathrm{1956)} \mathrm{and}$ $170 \mathrm{~mm}$ T.L. (Pearson, 1929) in southern locations, and over $200 \mathrm{~mm}$ T.L. in the Chesapeake Bay (Hildebrand and Schroeder, 1928). The largest male captured in the present study was $158 \mathrm{~mm} \mathrm{S.L}$. and was immature. Spot sonic muscle, however, first appeared in a specimen of $106 \mathrm{~mm}$ S.L., well before sexual maturity. Further, the muscle developed within the first year of age while sexual maturity in spot was not attained until the second or third year. Muscle development and the acceleration of gonad growth, however, did begin at the same time. As the rate of gonad growth increased, sonic muscle development was initiated. Development of both variables was concurrent from this point on .

Weakfish

The smallest male possessing sonic muscle was $119 \mathrm{~mm} \mathrm{~S} . \mathrm{L}$. which falls within the range of sexual maturity which Merriner (1976) found extended down to $105 \mathrm{~mm}$ S.L. in samples collected off the coast of North Carolina. Further, Merriner found most of the fish examined to be sexually mature by one year of age with some smaller individuals maturing at two years. The smallest specimen of the present study with developing sonic muscle,then, occured within the range of sexual development. As in croaker and spot, weakfish sonic muscle began as 
gonad growth increased in rate. At the same point that gonad development accelerated, sonic muscle development was initiated. Muscle growth was concurrent with gonad growth from this point. Only further research combining data on hormonal levels with muscle development can provide the answers to the question of control over development of the sonic muscle.

In all three species, one would expect a sensitivity to androgen production during some stage of development because of the sexual differences between males and females with respect to the presence of the sonic muscle or its relative size. According to Foster et al. (1983), steroidogenic activities have been detected very early in the immature testis (Oota and Yamamoto, 1966; Takahashi and Iwasaki, 1973; Satoh, 1974; Van Den Hurk, 1974; Nagahama et a1., 1978; Van Den Hurk et a1., 1982;). Interstitial cells, which exist in the interstitium between gonadal lobules and which have been implicated in other species as possible sites of steroidogenic activity, were not examined. These areas may yet be shown to be similarly active in early hormonal production in those species (such as spot) where muscle $t$ is sue occurs before gonadal spermatogenesis. Further research in this area may determine whether this sensitivity of sonic muscle to androgen production occurs and, if so, whether it occurs as a result of increased androgen output during sexual maturation. 
Appendix $\underline{A}$ - Croaker

\begin{tabular}{|c|c|c|c|c|c|c|c|}
\hline \multirow{3}{*}{ SEX } & STANDARD & BODY & \multirow{3}{*}{$\begin{array}{l}\text { BLADDER } \\
\text { WT ( } g \text { ) }\end{array}$} & \multirow{3}{*}{$\begin{array}{l}\text { GONAD } \\
\text { WT (g) }\end{array}$} & \multirow{3}{*}{$\begin{array}{l}\text { MUSCLE } \\
\text { WT (g) }\end{array}$} & \multicolumn{2}{|c|}{ MUSCLE } \\
\hline & LGTH (mm) & WT $(g)$ & & & & LENGTH (mm) & WIDTH (mm) \\
\hline & & & & & & L & L \\
\hline $\mathbf{F}$ & 044.0 & 001.70 & 0.02 & 0.0006 & 0.0000 & $-\infty-\infty-$ & $\ldots$ \\
\hline $\mathbf{F}$ & 045.0 & 001.90 & 0.02 & 0.0004 & 0.0013 & $-\cdots--\cdots$ & $-\cdots$ \\
\hline F & 047.0 & 002.10 & 0.02 & 0.0002 & 0.0029 & - - - - - - & -------- \\
\hline F & 050.0 & 002.60 & 0.04 & 0.0006 & 0.0033 & $---\cdots--$ & ----- \\
\hline F & 052.0 & 002.80 & 0.03 & 0.0013 & 0.0062 & $---\cdots--$ & - - - - \\
\hline $\mathbf{F}$ & 057.0 & 003.80 & 0.04 & 0.0012 & 0.0091 & $---\infty-\infty$ & $--\infty-\cdots$ \\
\hline $\mathbf{F}$ & 057.0 & 003.90 & 0.04 & 0.0023 & 0.0100 & --- - - - & $--\infty--$ \\
\hline $\mathbf{F}$ & 064.0 & 005.90 & 0.05 & 0.0030 & 0.0100 & $09.0 ; 09.0$ & $05.0 ; 05.0$ \\
\hline F & 068.0 & 006.20 & 0.06 & 0.0042 & 0.0200 & $07.0 ; 07.0$ & $05.0 ; 05.0$ \\
\hline F & 070.0 & 006.90 & 0.09 & 0.0025 & 0.0300 & $10.0 ; 09.0$ & $06.0 ; 06.0$ \\
\hline $\mathbf{F}$ & 071.0 & 008.10 & 0.07 & 0.0031 & 0.0200 & ------ & $-\cdots---\infty$ \\
\hline $\mathbf{F}$ & 074.0 & 009.35 & 0.08 & 0.0032 & 0.0400 & $11.0 ; 10.0$ & $06.0 ; 06.0$ \\
\hline F & 080.0 & 010.50 & 0.11 & 0.0051 & 0.0400 & $09.5 ; 09.5$ & $07.0 ; 07.0$ \\
\hline F & 081.0 & 010.80 & 0.12 & 0.0193 & 0.0800 & $14.0 ; 13.0$ & $07.0 ; 07.0$ \\
\hline $\mathbf{F}$ & 084.0 & 013.00 & 0.11 & 0.0113 & 0.0800 & $13.0 ; 13.0$ & $07.0 ; 07.0$ \\
\hline F & 085.0 & 012.30 & 0.13 & 0.0130 & 0.0900 & $13.0 ; 13.0$ & $08.0 ; 08.0$ \\
\hline $\mathbf{F}$ & 089.0 & 017.00 & 0.16 & 0.0052 & 0.0900 & $15.0 ; 14.0$ & $08.0 ; 08.0$ \\
\hline $\mathbf{F}$ & 090.0 & 015.60 & 0.17 & 0.0132 & 0.1100 & $16.0 ; 15.0$ & $08.0 ; 08.0$ \\
\hline $\mathbf{F}$ & 091.0 & 017.10 & 0.16 & 0.0092 & 0.1000 & $13.0 ; 13.0$ & $09.0 ; 09.0$ \\
\hline F & 092.0 & 018.30 & 0.22 & 0.0186 & 0.1200 & $14.0 ; 14.0$ & $09.0 ; 09.0$ \\
\hline F & 093.0 & 015.00 & 0.20 & 0.0325 & 0.1000 & $15.0 ; 15.0$ & $08.0 ; 07.5$ \\
\hline $\mathbf{F}$ & 099.0 & 020.44 & 0.20 & 0.0430 & 0.1600 & $18.0 ; 18.0$ & $11.0 ; 10.0$ \\
\hline $\mathbf{F}$ & 101.0 & 020.00 & 0.32 & 0.0376 & 0.1300 & $19.0 ; 19.0$ & $09.0 ; 09.0$ \\
\hline $\mathbf{F}$ & 108.0 & 025.94 & 0.37 & 0.0287 & 0.1900 & $20.0 ; 20.0$ & $11.0 ; 11.0$ \\
\hline $\mathbf{F}$ & 109.0 & 023.29 & 0.27 & 0.0590 & 0.2400 & $21.0 ; 20.0$ & $10.0 ; 10.0$ \\
\hline F & 115.0 & 029.38 & 0.45 & 0.0733 & 0.2600 & $21.0 ; 22.0$ & $12.0 ; 12.0$ \\
\hline F & 118.0 & 034.29 & 0.39 & 0.0743 & 0.2600 & $23.0 ; 22.0$ & $13.0 ; 13.0$ \\
\hline $\mathbf{F}$ & 118.0 & 036.40 & 0.64 & 0.0325 & 0.3800 & $22.5 ; 23.0$ & $10.0 ; 10.0$ \\
\hline $\mathbf{F}$ & 119.0 & 029.96 & 0.37 & 0.0775 & 0.2200 & $23.0 ; 21.0$ & $12.0 ; 12.0$ \\
\hline$F$ & 120.0 & 032.20 & 0.38 & 0.1082 & 0.2400 & $23.0 ; 22.0$ & $11.0 ; 12.0$ \\
\hline $\mathbf{F}$ & 123.0 & 034.40 & 0.45 & 0.0742 & 0.3100 & $27.0 ; 29.0$ & $10.5 ; 11.0$ \\
\hline $\mathbf{F}$ & 134.0 & 054.00 & 0.70 & 0.0809 & 0.4200 & $29.0 ; 29.0$ & $11.0 ; 11.0$ \\
\hline $\mathbf{F}$ & 135.0 & 052.05 & 0.78 & 0.1342 & 0.5000 & $26.0 ; 26.0$ & $14.0 ; 14.0$ \\
\hline $\mathbf{F}$ & 136.0 & 048.87 & 0.67 & 0.1631 & 0.5100 & $26.0 ; 26.0$ & $13.0 ; 13.0$ \\
\hline $\mathbf{F}$ & 139.0 & 056.90 & 0.60 & 0.1355 & 0.4900 & $22.0 ; 23.0$ & $12.0 ; 12.0$ \\
\hline $\mathbf{F}$ & 144.0 & 054.30 & 0.62 & 0.1121 & 0.5700 & $27.0 ; 27.0$ & $13.0 ; 14.0$ \\
\hline $\mathbf{F}$ & 146.0 & 069.20 & 0.79 & 0.1946 & 0.6500 & $28.0 ; 29.0$ & $14.0 ; 14.0$ \\
\hline $\mathbf{F}$ & 153.0 & 077.20 & 0.87 & 0.2230 & 0.7200 & $30.0 ; 30.0$ & $14.0 ; 14.0$ \\
\hline $\mathbf{F}$ & 159.0 & 088.60 & 1.04 & 0.3110 & 0.7500 & $32.0 ; 30.0$ & $13.0 ; 13.0$ \\
\hline $\mathbf{F}$ & 159.0 & 109.00 & 1.35 & 0.5518 & 0.9700 & $29.0 ; 30.0$ & $15.0 ; 16.0$ \\
\hline $\mathbf{F}$ & 162.0 & 087.50 & 1.02 & 0.2739 & 0.7600 & $29.0 ; 29.0$ & $13.0 ; 13.0$ \\
\hline $\mathbf{F}$ & 162.0 & 088.80 & 1.09 & 0.2560 & 0.8200 & $32.0 ; 32.0$ & $16.0 ; 17.0$ \\
\hline & & & & & & & \\
\hline
\end{tabular}


Appendix A (cont'd)

STANDARD BODY BLADDER GONAD MUSCLE

SEX LGTH (mm) WT (g) WT (g) WT (g) WT (g)

\begin{tabular}{|c|c|c|c|c|c|}
\hline $\mathbf{F}$ & 162.0 & 094.60 & 1.13 & 0.3078 & 0.89 \\
\hline F & 165.0 & 103.90 & 1.56 & 0.3305 & 0.98 \\
\hline F & 172.0 & 106.10 & 1.62 & 0.3771 & 1.02 \\
\hline F & 176.0 & 094.10 & 1.51 & 0.3609 & 1.05 \\
\hline F & 178.0 & 112.70 & 1.41 & 0.4554 & 0.910 \\
\hline F & 183.0 & 154.70 & 1.74 & 0.4779 & 1.27 \\
\hline$F$ & 185.0 & 136.70 & 1.59 & 0.3847 & 0.96 \\
\hline F & 187.0 & 133.70 & 1.47 & 0.4202 & 1.30 \\
\hline F & 188.0 & 144.50 & 1.87 & 0.5571 & 1.74 \\
\hline $\mathbf{F}$ & 190.0 & 161.20 & 2.49 & 0.5721 & 1.61 \\
\hline M & 043.0 & 001.70 & 0.02 & 0.0001 & 0.00 \\
\hline M & 045.0 & 001.80 & 0.02 & 0.0001 & 0.00 \\
\hline M & 054.0 & 003.00 & 0.03 & 0.0006 & 0.00 \\
\hline M & 062.0 & 005.10 & 0.05 & 0.0002 & 0.01 \\
\hline M & 068.0 & 007.20 & 0.05 & 0.0003 & 0.03 \\
\hline $\mathbf{M}$ & 070.0 & 007.70 & 0.07 & 0.0009 & 0.0 \\
\hline M & 072.0 & 008.10 & 0.07 & 0.0009 & 0.0 \\
\hline M & 077.0 & 009.40 & 0.09 & 0.0007 & 0.0 \\
\hline M & 078.0 & 011.10 & 0.10 & 0.0011 & 0.0 \\
\hline M & 085.0 & 014.10 & 0.12 & 0.0030 & 0.1 \\
\hline $\mathbf{M}$ & 088.0 & 014.22 & 0.18 & 0.0014 & 0.0 \\
\hline M & 091.0 & 015.10 & 0.20 & 0.0026 & 0.1 \\
\hline M & 091.0 & 016.40 & 0.17 & 0.0022 & 0.15 \\
\hline M & 093.0 & 017.40 & 0.13 & 0.0023 & 0.12 \\
\hline M & 094.0 & 016.70 & 0.15 & 0.0023 & 0.12 \\
\hline M & 096.0 & 018.88 & 0.25 & 0.0017 & 0.12 \\
\hline M & 096.0 & 020.35 & 0.18 & 0.0024 & 0.19 \\
\hline $\mathbf{M}$ & 097.0 & 020.10 & 0.24 & 0.0026 & 0.18 \\
\hline M & 099.0 & 015.60 & 0.18 & 0.0085 & 0.17 \\
\hline M & 102.0 & 023.79 & 0.35 & 0.0068 & 0.19 \\
\hline $\mathbf{M}$ & 103.0 & 022.47 & 0.32 & 0.0035 & 0.19 \\
\hline M & 104.0 & 021.66 & 0.31 & 0.0007 & 0.19 \\
\hline M & 109.0 & 025.98 & 0.32 & 0.0031 & 0.15 \\
\hline $\mathbf{M}$ & 121.0 & 040.12 & 0.57 & 0.0093 & 0.39 \\
\hline $\mathbf{M}$ & 124.0 & 038.30 & 0.56 & 0.0194 & 0.36 \\
\hline M & 133.0 & 057.00 & 0.62 & 0.0136 & 0.74 \\
\hline $\mathbf{M}$ & 134.0 & 045.41 & 0.76 & 0.0123 & 0.53 \\
\hline M & 134.0 & 055.49 & 0.71 & 0.0145 & 0.4 \\
\hline M & 136.0 & 043.30 & 0.50 & 0.0100 & 0.44 \\
\hline $\mathbf{M}$ & 136.0 & 047.60 & 0.64 & 0.0068 & 0.43 \\
\hline M & 139.0 & 052.77 & 0.76 & 0.0187 & 0.48 \\
\hline $\mathbf{M}$ & 149.0 & 071.70 & 0.90 & 0.0230 & 0.7 \\
\hline M & 155.0 & 075.30 & 1.09 & 0.0963 & 1.14 \\
\hline
\end{tabular}

\section{MUSCLE \\ $\operatorname{LENGTH}(\mathrm{mm})$ WIDTH (mm)}

$$
\begin{array}{llll}
\text { L } & \mathbf{R} & \mathbf{L} & \mathbf{R}
\end{array}
$$

$$
\begin{array}{ll}
33.0 ; 33.0 & 16.5 ; 17.0 \\
32.0 ; 31.0 & 15.0 ; 15.0 \\
34.0 ; 35.5 & 17.0 ; 17.0 \\
35.0 ; 38.0 & 18.0 ; 18.0 \\
35.0 ; 35.0 & 17.0 ; 17.0 \\
36.0 ; 35.0 & 17.5 ; 18.0 \\
34.0 ; 33.0 & 18.0 ; 17.0 \\
41.0 ; 40.0 & 15.0 ; 15.0 \\
38.0 ; 38.0 & 16.0 ; 16.0 \\
39.0 ; 40.0 & 17.0 ; 17.0
\end{array}
$$

- -...--

$06.0 ; 06.0 \quad 03.0 ; 04.0$

$09.0 ; 09.0 \quad 05.0 ; 05.0$

$09.0 ; 08.0 \quad 05.0 ; 05.0$

$11.0 ; 11.0 \quad 06.0 ; 06.0$

$09.0 ; 09.0 \quad 06.0 ; 06.0$

$09.0 ; 10.0 \quad 07.0 ; 07.0$

$14.0 ; 14.0 \quad 08.0 ; 08.0$

$17.0 ; 17.0 \quad 08.0 ; 08.0$

$16.0 ; 16.0 \quad 09.0 ; 09.0$

$17.0 ; 15.0 \quad 08.0 ; 08.0$

$17.0 ; 15.0 \quad 08.0 ; 09.0$

$14.0 ; 14.0 \quad 09.0 ; 09.0$

$19.0 ; 20.0 \quad 11.5 ; 11.0$

$15.0 ; 17.0 \quad 10.0 ; 10.0$

$19.0 ; 18.0 \quad 09.0 ; 09.0$

$23.0 ; 22.0 \quad 11.0 ; 11.0$

$22.0 ; 21.0 \quad 12.0 ; 11.5$

$20.0 ; 20.0 \quad 12.0 ; 12.0$

$19.0 ; 19.0 \quad 12.0 ; 12.0$

$27.0 ; 28.0 \quad 12.0 ; 12.0$

$27.0 ; 27.0 \quad 12.5 ; 12.0$

$25.0 ; 26.0 \quad 15.0 ; 15.0$

$29.0 ; 27.5 \quad 14.0 ; 14.0$

$28.0 ; 28.0 \quad 14.0 ; 14.0$

$29.0 ; 30.0 \quad 12.0 ; 12.0$

$28.0 ; 28.0 \quad 14.0 ; 15.0$

$27.5 ; 27.0 \quad 14.0 ; 14.0$

$32.0 ; 30.0 \quad 15.0 ; 16.0$

$33.0 ; 34.0 \quad 15.0 ; 14.0$ 
Appendix A (cont ${ }^{\circ}$ d)

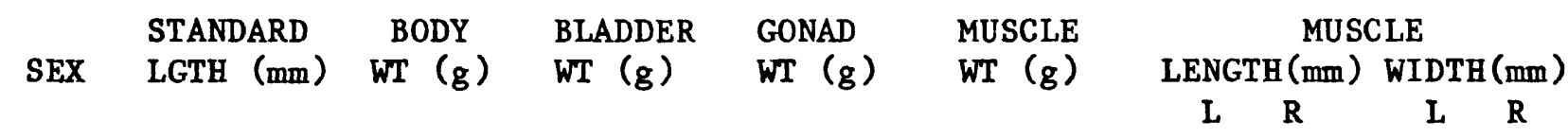

$\begin{array}{llllllll}M & 155.0 & 079.30 & 1.09 & 0.0643 & 1.0000 & 33.0 ; 35.0 & 16.0 ; 16.0 \\ M & 161.0 & 091.80 & 1.45 & 0.0282 & 1.0500 & 34.0 ; 33.0 & 18.0 ; 17.5 \\ M & 164.0 & 086.50 & 0.92 & 0.0767 & 0.8500 & 37.0 ; 36.0 & 17.0 ; 16.0 \\ M & 166.0 & 105.40 & 1.67 & 0.0264 & 1.1400 & 33.0 ; 32.0 & 18.0 ; 18.0 \\ M & 168.0 & 079.90 & 1.31 & 0.0659 & 0.8300 & 36.0 ; 36.0 & 16.5 ; 16.5 \\ M & 170.0 & 103.80 & 1.32 & 0.0803 & 1.6000 & 38.0 ; 38.0 & 14.0 ; 14.0 \\ M & 182.0 & 146.60 & 2.07 & 0.1025 & 2.0800 & 42.0 ; 42.0 & 15.0 ; 15.0 \\ M & 183.0 & 111.40 & 1.51 & 0.1741 & 1.4800 & 44.0 ; 44.0 & 16.0 ; 16.0 \\ M & 184.0 & 168.50 & 2.69 & 0.1378 & 2.1100 & 44.0 ; 42.0 & 16.0 ; 15.0 \\ M & 188.0 & 123.00 & 2.06 & 0.0836 & 1.6400 & 42.0 ; 42.0 & 17.0 ; 17.0\end{array}$


Append ix $\underline{B}$ - Spot

\begin{tabular}{|c|c|c|c|c|c|c|c|}
\hline \multirow{3}{*}{ SEX } & \multirow{3}{*}{$\begin{array}{l}\text { STANDARD } \\
\text { LGTH (mm) }\end{array}$} & \multirow{3}{*}{$\begin{array}{c}\text { BODY } \\
\text { WT }(g)\end{array}$} & \multirow{3}{*}{$\begin{array}{l}\text { BLADDER } \\
\text { WT }(\mathrm{g})\end{array}$} & \multirow{3}{*}{$\begin{array}{l}\text { GONAD } \\
\text { WT (g) }\end{array}$} & \multirow{3}{*}{$\begin{array}{l}\text { MUSCLE } \\
\text { WT (g) }\end{array}$} & \multicolumn{2}{|c|}{ MUSCLE } \\
\hline & & & & & & LENGTH (mm) & WIDTH (mm) \\
\hline & & & & & & L & L \\
\hline $\mathbf{M}$ & 090.0 & 018.88 & 0.13 & 0.0100 & 0.0000 & $\ldots$ & \\
\hline $\mathbf{M}$ & 098.0 & 024.59 & 0.14 & 0.0063 & 0.0000 & -ー-ー- - & -- \\
\hline $\mathbf{M}$ & 101.0 & 029.20 & 0.15 & 0.0032 & 0.0000 & $-\cdots$ & -- \\
\hline M & 106.0 & 034.10 & 0.17 & 0.0021 & 0.0029 & $-\cdots$ & - \\
\hline $\mathbf{M}$ & 108.0 & 030.90 & 0.14 & 0.0027 & 0.0065 & $----\infty---$ & $-\cdots$ \\
\hline M & 111.0 & 039.50 & 0.17 & 0.0056 & 0.0100 & - & $-\infty$ \\
\hline $\mathbf{M}$ & 112.0 & 035.90 & 0.13 & 0.0040 & 0.0046 & $\ldots$ & $-\cdots$ \\
\hline M & 112.0 & 037.40 & --- & 0.0024 & 0.0000 & $-\cdots$ & -- \\
\hline $\mathbf{M}$ & 114.0 & 037.80 & 0.12 & 0.0042 & 0.0000 & $-\cdots$ & $-\cdots$ \\
\hline $\mathbf{M}$ & 114.0 & 039.00 & 0.16 & 0.0013 & 0.0067 & --- & 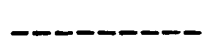 \\
\hline $\mathbf{M}$ & 115.0 & 035.50 & 0.18 & 0.0062 & 0.0300 & -ー-ー- & -- \\
\hline M & 115.0 & 041.00 & 0.13 & 0.0038 & 0.0000 & - - - & -- \\
\hline $\mathbf{M}$ & 115.0 & 041.40 & 0.13 & 0.0017 & 0.0000 & $\ldots$ & - \\
\hline $\mathbf{M}$ & 116.0 & 035.40 & 0.18 & 0.0103 & 0.0300 & $-\cdots$ & $\ldots$ \\
\hline $\mathbf{M}$ & 116.0 & 042.80 & 0.17 & 0.0058 & 0.0200 & $\ldots$ & -n- \\
\hline $\mathbf{M}$ & 116.0 & 043.00 & 0.21 & 0.0043 & 0.0076 & $--\cdots$ & -- \\
\hline $\mathbf{M}$ & 117.0 & 042.80 & 0.16 & 0.0015 & 0.0000 & $\cdots$ & $-\infty$ \\
\hline $\mathbf{M}$ & 118.0 & 043.40 & 0.20 & 0.0121 & 0.0200 & $-\infty---$ & $--\infty-\infty--$ \\
\hline $\mathbf{M}$ & 123.0 & 057.30 & 0.23 & 0.0204 & 0.1100 & $21.0 ; 21.0$ & $07.0 ; 07.0$ \\
\hline $\mathbf{M}$ & 128.0 & 060.00 & 0.27 & 0.0173 & 0.0500 & $20.0 ; 18.0$ & $06.0 ; 05.0$ \\
\hline $\mathbf{M}$ & 129.0 & 057.50 & 0.20 & 0.0143 & 0.0700 & $29.0 ; 27.0$ & $08.0 ; 07.0$ \\
\hline $\mathbf{M}$ & 143.0 & 069.70 & 0.37 & 0.0187 & 0.0700 & $22.0 ; 22.0$ & $06.0 ; 06.0$ \\
\hline $\mathbf{M}$ & 144.0 & 082.20 & 0.50 & 0.0229 & 0.1200 & $21.0 ; 20.0$ & $04.0 ; 05.0$ \\
\hline M & 146.0 & 078.00 & 0.29 & 0.0323 & 0.1100 & $21.0 ; 20.0$ & $06.0 ; 06.0$ \\
\hline $\mathbf{M}$ & 156.0 & 108.80 & 0.53 & 0.0218 & 0.2100 & $27.0 ; 28.0$ & $09.0 ; 09.0$ \\
\hline $\mathbf{M}$ & 158.0 & 093.50 & 0.44 & 0.0244 & 0.1500 & $29.0 ; 29.0$ & $07.0 ; 07.0$ \\
\hline $\mathbf{M}$ & 165.0 & 129.10 & 0.74 & 0.0239 & 0.2100 & $32.0 ; 32.0$ & $08.0 ; 08.0$ \\
\hline
\end{tabular}


Appendix $\underline{C}$ - Weakfish

\begin{tabular}{|c|c|c|c|c|c|c|c|}
\hline \multirow{3}{*}{ SEX } & \multirow{3}{*}{$\begin{array}{l}\text { STANDARD } \\
\text { LGTH (mm) }\end{array}$} & BODY & BLADDER & \multirow{2}{*}{$\begin{array}{l}\text { GONAD } \\
\text { WT (g) }\end{array}$} & \multirow{3}{*}{$\begin{array}{l}\text { MUSCLE } \\
\text { WT }(g)\end{array}$} & \multicolumn{2}{|c|}{ MUSCLE } \\
\hline & & WT (g) & WT $(g)$ & & & LENGTH (mm) & WIDTH (mm) \\
\hline & & & & & & $\mathbf{L}$ & L \\
\hline $\mathbf{M}$ & 119.0 & 029.60 & 0.50 & 0.0093 & 0.0077 & -- & -- \\
\hline M & 125.0 & 038.40 & 0.68 & 0.0230 & 0.0900 & $29.0 ; 28.0$ & $08.0 ; 08.0$ \\
\hline $\mathbf{M}$ & 126.0 & 032.28 & 0.91 & 0.0339 & 0.0000 & - & $-\infty-\infty$ \\
\hline $\mathbf{M}$ & 129.0 & 039.30 & 0.62 & 0.0174 & 0.0000 & $-\infty----$ & $--\infty-\infty$ \\
\hline $\mathbf{M}$ & 132.0 & 034.80 & 0.72 & 0.0447 & 0.0900 & $27.0 ; 27.0$ & $10.0 ; 10.0$ \\
\hline M & 134.0 & 031.30 & 1.04 & 0.0721 & 0.1100 & $28.0 ; 21.0$ & $10.0 ; 09.0$ \\
\hline M & 135.0 & 037.40 & 0.83 & 0.0102 & 0.0400 & $-\infty-\infty-\infty$ & 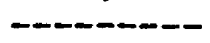 \\
\hline $\mathbf{M}$ & 136.0 & 048.60 & 0.89 & 0.0227 & 0.1200 & $33.0 ; 32.0$ & $08.0 ; 08.0$ \\
\hline $\mathbf{M}$ & 139.0 & 048.30 & 1.02 & 0.2022 & 0.3200 & $37.0 ; 33.0$ & $09.0 ; 09.0$ \\
\hline $\mathbf{M}$ & 139.0 & 049.60 & 0.94 & 0.0940 & 0.1700 & $28.0 ; 29.0$ & $10.0 ; 10.0$ \\
\hline $\mathbf{M}$ & 147.0 & 053.18 & 1.19 & 0.0339 & 0.1000 & -- & $\cdots$ \\
\hline $\mathbf{M}$ & 147.0 & 060.50 & 1.15 & 0.4658 & 0.6700 & $40.0 ; 40.0$ & $15.0 ; 15.0$ \\
\hline $\mathbf{M}$ & 148.0 & 051.60 & 1.40 & 0.4460 & 0.3500 & $35.0 ; 35.0$ & $11.0 ; 11.0$ \\
\hline $\mathbf{M}$ & 153.0 & 058.80 & 1.24 & 0.6488 & 0.5300 & $40.0 ; 35.0$ & $12.0 ; 12.0$ \\
\hline $\mathbf{M}$ & 155.0 & 068.60 & 2.12 & 0.7333 & 0.8600 & $42.0 ; 42.0$ & $15.0 ; 15.0$ \\
\hline$M$ & 156.0 & 062.30 & 1.17 & 0.3221 & 0.3900 & $45.0 ; 43.0$ & $13.0 ; 13.0$ \\
\hline $\mathbf{M}$ & 158.0 & 065.30 & 1.35 & 0.6736 & 0.7700 & $42.0 ; 42.0$ & $13.0 ; 13.0$ \\
\hline M & 160.0 & 070.70 & 1.59 & 0.2576 & 0.2800 & $33.0 ; 33.0$ & $15.0 ; 15.0$ \\
\hline $\mathbf{M}$ & 164.0 & 079.90 & 1.38 & 0.1372 & 0.3800 & $42.0 ; 36.0$ & $12.0 ; 12.0$ \\
\hline M & 172.0 & 093.90 & 1.98 & 0.4184 & 0.9300 & $50.0 ; 50.0$ & $18.0 ; 18.0$ \\
\hline M & 174.0 & 089.60 & 1.93 & 0.8542 & 1.1200 & $47.0 ; 46.0$ & $18.0 ; 18.0$ \\
\hline M & 179.0 & 107.90 & 2.33 & 1.3494 & 1.6300 & $51.0 ; 51.0$ & $19.0 ; 19.0$ \\
\hline $\mathbf{M}$ & 182.0 & 103.57 & 3.31 & 0.6974 & 0.8700 & $47.0 ; 47.0$ & $15.0 ; 15.0$ \\
\hline
\end{tabular}




\section{LITERATURE CITED}

Bigelow, H.B., and Schroeder, W.C. 1923. Fishes of the Gulf of Maine. U.S. Fish. Wild. Serv,, Fish. Bull. 53, 577 p.

Carter, H.J., and Musick, J.A. 1985. Sexual dimorphism in the deep-sea fish Barathrodemus manatinus (Ophidiidae). Copeia 1: 69-73.

Chabanaud, Paul 1929. La toxonomie, la morphologie, et la bionomie des Soleides du genre Pegusa. Ann. Inst. Oceangr. Vol 7, Fasc. 6, pp 215261.

Chao, L.N. 1978. A basis for classifying western Atlantic Sciaenidae (Teleostei:Perciformes). NOAA Technical Report NMFS Circular 415.

Chao, L.N. and Musick, J.A. 1977. Life history, feeding habits, and functional morphology of juvenile sciaenid fishes in the York River estuary, Virginia. Fish. Bul1. 75: 657-702.

Dawson, C.E. 1958. A study of the biology and life history of the spot Leiostomus xanthurus Lacepede, with special reference to South

Carolina. Bears Bluff Lab. 28: 3-48.

Dijkgraaf, S. 1947. A sound producing fish in the Naples Aquarium. Experimentia. 3: 1-4.

Fine, M.L. 1975. Sexual dimorphism of the growth rate of the swimbladder of the toadfish (Opsanus tau). Copeia 1955. 483-490.

Fine, M.L. and Pennypacker, R.R. 1985. The hormonal basis for sexual dimorphism of the sound-producing apparatus of the oyster toadfish. Exp. Neurol. submitted.

Fish, J.F . and Cummings, W.C. 1972. A $50 \mathrm{db}$ increase in sustained ambient noise from fish (Cynoscion regalis). J. Acoust. Soc. of Amer. 52: $1266-1270$.

Fish, M.P. 1954. The character and significance of sound production among fishes of the western North Atlantic. Bull. Bing. Oceang. Col. XIV: 3-109.

Fish, M.P. and Mowbray, W.H. 1970. Sounds of Western North At lantic Fishes. John Hopkins Press, Baltimore.

Foster, A., Jalabert, B., Billard, R., Breton, B. 1983. The Gonadal Steroids. In Fish Physiology; ed. by W.S. Hoar, D.J. Randa11, and E.M. Donaldson. Vol. 9A, Pp 277-372. 
Gray, G.A. and Winn, H.E. 1961. Reproductive ecology and sound production of the toadfish, Opsanus tau. Ecology. 42: 274-282

Guest, W.C. and Lasswell, J.L. 1978. A note on courtship behavior and sound production of red drum. Copeia. 2: 337-338.

Hildebrand, S.F. and Cable, L. 1930. Development and life history of fourteen fishes at Beaufort, North Carolina. Bull. U.S. Bur. Fish. 46: $383-488$.

Hildebrand, S.F. and Schroeder, W.C. 1928. Fishes of the Chesapeake Bay. Bu11. U.S. Bur. Fish. 43: 1-366.

Marshall, N.B. 1962. Biology of sound producing fishes. Symp. Soc. London. 7 : 45-60.

- 1967. Sound producing mechanisms and the biology of deep-sea fishes. In Marine Bio-acoustics II; ed. by Tavolga. Peragamon Press, 0xford. 123-133.

Merriner, J.V. 1976. Aspects of the reproductive biology of the weakf ish Cynoscion regalis (Sciaenidae) in North Carolina. Fish. Bull., U.S. 74: 18-26.

Nagahama, Y., Clarke, W.C. and Hoar, W.S. 1978. Ultrastructure of putative steroid-producing cells in the gonads of coho Oncorhynchus kisutch and pink salmon Oncorhynchus gorbuscha. Can. J. Zool. 56: 25082519 .

Norcross, B.L. 1983. Climate scale environmental factors affecting year-class fluctuations of At lantic croaker (Micropogonias undulatus) in the Chesapeake Bay. PhD Dissertation. Virginia Institute of Marine Science, College of William and Mary, Gloucester Point, Va.

Ono, R.D. and Poss, S.G. 1981. Structure and innervation of the swimbladder musculature in the weakfish, Cynoscion regalis (Teleostei: Sciaenidae). Can. J. Zool. 60: 1955-1967.

Oota, I., and Yamamoto, K. 1966. Interstitial cells in the immature testes of the rainbow trout. Annot. Zool. Jpn. 39: 142-148.

Overstreet,R.M. 1983. Aspects of the biology of the spotted sea trout, Cynoscion nebulosis, in Mississippi. Gulf Res. Rep. Supp. 1: 1-43.

Pacheco, A.L. 1957. The length and age composition of spot Leiostomus xanthurus in the pound net fishery of lower Chesapeake Bay. Unpublished M.S. thesis, College of William and Mary. 34 pp. 
Parker, J.C. 1971. The biology of the spot Leiostomus xanthurus Lacepede, and At lantic croaker Micropogon undulatus in two Gulf of Mexico nursery areas. Sea Grant Pub. No. TAMU-SG 71-210. 182 p.

Pearson, J.C. 1929. Natural history and conservation of red fish and other commercial sciaenids on the Texas coast. Bull. U.S. Bur. Fish. 44: 129-214.

-.. 1941. The young of some marine fishes taken in lower Chesapeake Bay. Virginia, with special references to the gray sea trout Cynoscion regalis $(B l o c h)$. Bull. U.S. Fish, and Wildl. Serv. 50: 79102.

Satoh, N. 1974. An ultrastructural study of sex differentiation in the teleost Oryzias latipes. J. Embryol. Exp. Morphol. 32: 195-215.

Takahashi, H. and Iwasaki, Y. 1973. Occurence of histochemical activity of 3B-hydroxysteroid dehydrogenase in developing testes of Poecilia reticulata. Dev., Growth Differ. 15: 241-253.

Takemura, A., Takita, T., Mizue, K. 1977. Underwater calls of the Japanese marine drum fish (Sciaenidae). Bull. Jap. Soc. of Sci. Fish. 44: $121-125$.

Templeman, W. and Hodder, V.M. 1956. Variation with $f$ ish length, sex, stage of sexual maturity, and season in the appearance and volume of the drumming muscles of the swimbladder in the haddock Melanogrammus aeglefinus. J. Fish. Res. Bd. Can. 15: 355-390.

Tower, R.W. 1908. The production of sound in the drum fishes, the sea robin, and the toadfish. Ann. N.Y. Acad. Sci. 18: 149-180.

Townshend, B.C.Jr. 1956. A study of the spot, Leiostomus xanthurus Lacepede, in Alligator Harbor, Florida. Unpublished M.S. Thes is. Oceanogr. Inst. Fla. State Univ. 43pp.

Tracy, H.C. 1959. Stages in the development of the anatomy of motility of the toadfish (Opsanus tau). J. Comp. Neuro 1. 111: 27-81.

- - 1961. Development of the spinal crest, nerves and muscles in the toadfish (Opsanus tau). J. Comp. Neurol. 116: 291-340.

Van Den Hurk, R. 1974. Steroidogenesis in the testis and gonadotropic activity in the pituitary during post natal development of the black molly Mollienisia latipinna. Proc. K. Ned. Akad. Wet., Ser. C 77:193200 .

Van Den Hurk, R., Lambert, J.G.D., and Peute, J. 1982. Steroidogenes is in the gonads of rainbow trout fry Salmo gairdneri before and after the onset of gonadal sex differentiation. Reprod. Nutr. Devlop. 22: 413426. 
Wallace; D.H. 1940. Sexual development of the croaker Micropogon undulatus, and distribution of the early syages in Chesapeake Bay. Trans. Amer. Fish. Soc. 70: 475-482.

Welsh, W.W. and Breeder, C.M.Jr. 1923. Contributions to life histories of Sciaenidae of the eastern United States coast. Bull. U.S. Bur. Fish. 39: 141-201.

White,M.L. and Chittendon, M.E. 1977. Age determination, reproduction and population dynamics of the At lantic croaker Micropogonias undulatus. Fish. Bull., U.S. 75: 109-123.

Wilk, S.J. 1978. Biology and ecology of the weakfish Cynoscion regalis (Bloch and Schneider). In Colloquium on the Biology and Management of Red Drum and Sea Trout. May 1980. no. 5.

Zar,J.H. 1974. Biostatistical Analysis. Prentice-Hall, Inc., Englewood Cliffs, N.J. 
VITA

Born at Fort Meade, Maryland, January 9, 1958. Received High School diploma from Menchville High School, Newport News, Virginia, 1976. Received B.S. in biological sciences from Virginia Polytechnic Institute and State University, 1980. In January, 1981, entered the School of Marine Science of the College of William and Mary in Virginia (Virginia Institute of Marine Science). 